NBER WORKING PAPER SERIES

\title{
CARROTS, STICKS AND BROKEN WINDOWS
}

\author{
Hope Corman \\ Naci Mocan \\ Working Paper 9061 \\ http://www.nber.org/papers/w9061 \\ NATIONAL BUREAU OF ECONOMIC RESEARCH \\ 1050 Massachusetts Avenue \\ Cambridge, MA 02138 \\ July 2002
}

This research is supported by the Independent Budget Office (IBO) of New York City. Kaj Gittings and Alicia Edwardson provided excellent research assistance. We wish to thank Preston Niblack and Bernard O'Brien for their suggestions and overall help. The views expressed herein are those of the authors and not necessarily those of the National Bureau of Economic Research or the IBO.

(C) 2002 by Hope Corman and Naci Mocan. All rights reserved. Short sections of text, not to exceed two paragraphs, may be quoted without explicit permission provided that full credit, including $(\mathrm{C}$ notice, is given to the source. 
Carrots, Sticks and Broken Windows

Hope Corman and Naci Mocan

NBER Working Paper No. 9061

July 2002

JEL No. K4, J18

\begin{abstract}
This paper investigates the impact of economics conditions (carrots) and sanctions (sticks) on murder, assault, robbery, burglary and motor vehicle theft in New York City, using monthly time-series data spanning 1974-1999. Carrots are measured by the unemployment rate and the real minimum wage; sticks are measured by felony arrests, police force and New York City residents in prison. In addition, the paper tests the validity of the "broken windows" hypothesis, where misdemeanor arrests are used as a measure of broken windows policing. The broken windows hypothesis has validity in case of robbery and motor vehicle theft. The models explain between 33 and 86 percent of the observed decline in these crimes between 1990 and 1999. While both economic and deterrence variables are important in explaining the decline in crime, the contribution of deterrence measures is larger than those of economic variables.
\end{abstract}

Hope Corman

Rider University

Department of Economics

2083 Lawrenceville Rd.

Lawrenceville, NJ 08648

and NBER

corman@rider.edu
Naci Mocan

University of Colorado at Denver Department of Economics, Box 181

Campus Box 173364

Denver, CO 80217-3364

and NBER

nmocan@carbon.cudenver.edu 


\section{Carrots, Sticks and Broken Windows}

\section{Introduction}

In the decade ending in 1999, there were significant drops in serious crime throughout the United States. From 1990 to 1999, violent crime rates fell by about 28\% and property crime rates fell by about $26 \%$ nationally. $\square_{\text {Many metropolitan areas fared }}$ even better than national trends in crime reduction. The drop in violent crime rates in Atlanta, Boston, Chicago, Los Angeles, Miami and San Diego ranged from 33 percent to 53 percent. 2 Although it followed the general trends, New York City experienced even more dramatic declines in crime: violent crimes declined by over $56 \%$ and property crimes fell by about $65 \%$ in the 1990 s. Many attribute New York's crime reduction to specific policies carried out by Mayor Rudolph Giuliani's administration, with its "gettough" approach to crime fighting. The most prominent of the policy changes was the aggressive policing of lower-level crimes, a policy which has been called "broken windows" approach to law enforcement. Skeptics believe that New York City's experience was attributable to other factors such as economic boom of the 1990s, enjoyed both in New York City and nationally. For example, the national unemployment rate declined by 25\% between 1990 and 1999, and it declined by 39\% between 1992 and 1999 in New York City.

\footnotetext{
${ }^{1}$ Source: US Department of Justice, Bureau of Labor Statistics, Sourcebook of Criminal Justice Statistics, 2000.

${ }_{2}$ Source: US Department of Justice, Bureau of Labor Statistics, Sourcebook of Criminal Justice Statistics, 2000 and 1991.

${ }^{3}$ Another explanation which is offered as a factor that has contributed to the drop in crime is reduction in the cohort size due to decline in fertility because of the legalization of abortion in the U.S. following the 1973 Supreme Court decision in Roe versus Wade. (Donahue and Levitt 2001). If most of the averted pregnancies are to women with economically disadvantaged backgrounds, then the legalization of abortion reduces the number of crime-prone children, and this would have an impact on crime 16-20 years after the legalization. We do not directly address the impact of legalized abortion on crime in New York City. However, in footnote 31 we discuss the potential relevance of this issue.
} 
The question of whether economic conditions or deterrence policies are more effective tools of crime control has become an important political issue in other countries as well. For example, France's prime minister, Lionel Jospin, indicated that he was "naive" to believe that lowering unemployment would solve crime problem in France, and in both Britain and France, conservative as well as liberal politicians are proposing "get-tough" policies in addition to economic ones in order to battle their rising crime rates (Nichols, 2002).

The aim of this paper is twofold. First, it analyzes the impact of economic conditions (carrots) and various deterrence measures (sticks) on five different index crimes in New York City between 1974 and 1999. The ability to include these variables jointly in a crime supply equation allows us to determine the relative magnitudes of economic and deterrence measures in a coherent framework. The second contribution of the paper is the investigation of the validity of the "broken windows" hypothesis, which is summarized in a press conference of New York City mayor Rudolph W. Guiliani on February 24, 1998, where he stated:

[... We have made the "Broken Windows" theory an integral part of our law enforcement strategy. This theory says that the little things matter. As James Q. Wilson describes it, "If a factory or office window is broken, passersby observing it will conclude that no one cares or no one is in charge. In time, a few will begin throwing rocks to break more windows. Soon all the windows will be broken, and now passersby will think that, not only no one is in charge of the building, no one is in charge of the street on which it faces. So, more and more citizens will abandon the street to those they assume prowl it. Small disorders lead to larger ones, and 
perhaps even to crime."... There's a continuum of disorder. Obviously murder and graffiti are two vastly different crimes. But they are part of the same continuum, and a climate that tolerates one is more likely to tolerate the other.]

In this paper, we use monthly time-series data between 1970 and 1999 from New York City to investigate the extent to which carrots (the unemployment rate and the real minimum wage), sticks (arrests, police force and prison population), and the "broken windows" approach to crime control are responsible for the drop in NYC crime from early-to-late 1990s. We use misdemeanor arrests as a measure of the extent of the "broken windows" approach to policing, and find support for the broken windows hypothesis in case of robberies and motor vehicle thefts. Although carrots and sticks both explain crime fluctuations in New York City, the impact of sticks was found to be stronger than the impact of carrots during the1990s.

In section II we briefly summarize recent literature on the economics of crime, and provide a description of the broken windows hypothesis. Sections III and IV present the empirical model and the data, respectively. Section V contains the results and Section VI is the conclusion.

\section{Literature Review and "Broken Windows"}

\section{A. The Impact of Sanctions and Economic Conditions on Crime.}

Recent research has demonstrated a significant impact of sanctions on criminal activity. [Mustard (forthcoming), Mocan and Gittings (2002), Corman and Mocan

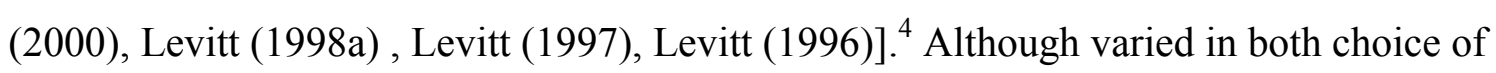

\footnotetext{
${ }^{4}$ What these articles have in common is an attempt to address some of the empirical issues which have made identification of the crime supply function so difficult. Two articles by Levitt, (1996 and 1997), for example, use election- or litigation-related variables as instruments to help identify the crime supply
} 
variables and econometric technique, each of these papers addresses previous empirical problems (mainly the simultaneity between deterrence and crime), and all find that variables related to expected punishment are more significantly related to crime than in the previous studies. Even though earlier work on joblessness-crime and wages-crime relationships did not provide conclusive evidence (See Corman et al. 1987, and Freeman 1983 and 1995 for reviews), recent papers demonstrated a stronger impact of labor market conditions on crime. [Gould, Mustard and Weinberg (2002), Raphael and Winter-Ebmer (2001), Freeman and Rodgers (2000), Grogger (1998)]. However, whether economic conditions or deterrence measures have a larger impact on crime is an unresolved issue. Data limitations prevented most research from simultaneously controlling for the impact of labor market variables and deterrence measures. Micro data sets may contain information on individuals' criminal behavior and their wages and unemployment spells, but they typically lack information on deterrence measures. Researchers who employ aggregate data sets did not always include extensive deterrence and economic variables. ${ }^{6}$ As a result, much of the current inference about the relative

function. Another article by Levitt (1998a) used cross-crime arrest rates to distinguish between deterrence and incapacitation effects. Corman and Mocan (2000) use high-frequency data and modern time-series techniques to circumvent the simultaneity issue between deterrence and crime. Mocan and Gittings (2002) use panel data that contain detailed information on death row inmates to assess the impact of executions and removals from death row on homicide. Mustard (forthcoming) includes convictions and length of imprisonment to investigate the extent of the omitted variable bias.

${ }^{5}$ For example, Grogger (1998) investigated the impact of wages on youth crime, but the NLSY data he used did not include measures of sanctions. Hashimoto (1987) used arrests as a proxy for crime and investigated the impact of minimum wages on youth crime with no controls for deterrence.

${ }^{6}$ For example, in their investigation of the effect of unemployment on crime Raphael and Winter-Ebmer (2001) included only state prison population as a control. Gould, Mustard and Weinberg (2002) focus on the impact of local labor market conditions on crime. They add county arrest rates and state-level per capita police spending and police employment in county-level crime regressions in one of their specifications, but exclude them from their analysis in other models they estimate. 
impact of economic conditions and sanctions rely on information obtained from multiple papers which use different data sets and employ different empirical methods. ${ }^{\text {. }}$

\section{B. Broken Windows.}

In an often-cited Atlantic Monthly article, Wilson and Kelling (1982) discuss the importance of maintaining public order. They argue that, at the community level, toleration of a high level of disorder results in crime. They use the image of the broken window to make the case that visible signs of tolerance of disorder lead to escalating levels of disorder and crime. They also posit that aggressive policing strategies, especially strategies which target high-frequency, low-level crimes, will be effective in deterring crimes.

It is suggested that a community with a strong level of social order will experience lower crime levels than low social-order communities for several reasons. First, these communities possess organizations and relationships which both empower residents to protect themselves against criminals and also encourage them to identify and protect others against ill-intentioned intruders. In this case, criminals will be deterred because potential victims, crime reporters and witnesses will make the job harder for potential criminals. Thus, a community with a strong level of social organization will be harder (more costly) to victimize. Second, in strong communities with low levels of "social disorder", criminal behavior on the part of residents is considered socially unacceptable. Children, teens, and young adults from these communities will experience more disutility from committing crimes than others because they will violate community values more than others. For these two reasons, strong communities deter crime by raising the costs to the criminal. In turn, social order can be enhanced by criminal justice

\footnotetext{
${ }^{7}$ See Freeman (1999) for a recent summary.
} 
policies which send signals that crime will not be tolerated in the community (Kahan, 1998). Finally, order-maintenance policing can reduce crime in a third way. By stopping and questioning individuals who are acting suspiciously, some serious felons may be apprehended. (Sampson and Cohen, 1988).

Although the literature provides plausible theoretical reasons for why aggressive policing of minor crimes may deter felonies, the small number of empirical studies do not shed substantial light on the issue because of their empirical shortcomings. For example, in addition to standard identification difficulties, these papers suffer from omitted variable biases. This is because they include a measure of police aggressiveness to the model without controlling for other deterrence measures. Allowing one key variable (such as police aggressiveness) to increase without holding constant other criminal justice variables may lead to misleading results. One possibility would be that the growth in police aggressiveness may occur because of an overall growth in police resources. Thus, the indicator of police aggressiveness may simply be acting as a proxy for felony arrests or the size of the police force, and the "broken windows" effects would be overstated. In this paper we measure the extent of the "broken windows" policing by using misdemeanor arrests as a measure of police signaling, in a model that controls for the number of police as well as felony arrests. Increased misdemeanor arrests may reduce

\footnotetext{
${ }^{8}$ Sampson and Cohen (1988) investigated the effects of "aggressive" policing on serious crime rates, where police aggressiveness is measured as the sum of the number of arrests for disorderly conduct and driving while intoxicated per police officer. Using a cross-sectional data of 156 cities, in a model that did not control for felony arrests, they reported an inverse relationship between police aggressiveness and the robbery crime rate. Giacopassi and Forde (2000) test the "broken windows" hypothesis using motor vehicle fatality rates as a measure of social disorder. In a cross section of two time periods, they find that traffic fatalities are significantly related to homicides after controlling for the number of police (but not homicide arrest rate), and population. They conclude that social disorder, captured by motor vehicle fatalities, causes homicide. Kelling and Sousa (2001) examine the effect of misdemeanor arrests on police precincts for two years in New York City. They conclude that "broken windows" policing works, but in this study both felony arrests and the size of the police are omitted from the analysis, and number of misdemeanor arrests is the only criminal justice-related variable.
} 
felony crimes by providing a signal regarding enhanced commitment and effectiveness of the police force in reducing all types of crime. Alternatively, increased misdemeanor arrests may reduce felony crimes by incapacitating individuals who would have committed those crimes in the absence of the misdemeanor arrests. We document later in the paper that incapacitation is not a plausible explanation for a negative relationship between misdemeanor arrests and felony crimes.

\section{Empirical Model}

We estimate crime equations of the following form.

$$
\begin{aligned}
& \mathrm{CR}_{\mathrm{it}}=\lambda_{\mathrm{i}}+\Sigma \alpha_{\mathrm{ij}} \mathrm{CR}_{\mathrm{i}, \mathrm{t}-\mathrm{j}}+\Sigma \beta_{\mathrm{iq}} \mathrm{UR}_{\mathrm{t}-\mathrm{q}}+\Sigma \gamma_{\mathrm{ir}} \mathrm{RMINW}_{\mathrm{t}-\mathrm{r}}+\Sigma \delta_{\mathrm{ik}} \mathrm{ARR}_{\mathrm{i}, \mathrm{t}-\mathrm{k}}+\Sigma \pi_{\mathrm{in}} \mathrm{PRIS}_{\mathrm{t}-\mathrm{n}} \\
& +\Sigma \phi_{\mathrm{ip}} \mathrm{POL}_{\mathrm{t}-\mathrm{p}}+\Sigma \eta_{\mathrm{im}} \mathrm{MISARR}_{\mathrm{t}-\mathrm{m}}+\Sigma \mu_{\mathrm{t}-\mathrm{s}} \mathrm{TEENS}_{\mathrm{t}-\mathrm{s}}+\Sigma \varphi_{\mathrm{iw}} \mathrm{SEAS}_{\mathrm{w}}+\varepsilon_{\mathrm{it}},
\end{aligned}
$$

where $\mathrm{CR}_{\mathrm{i}, \mathrm{t}}$ stands for $\mathrm{i}$ th crime in month $\mathrm{t}(\mathrm{i}=1$ : Murder, $\mathrm{i}=2$ : Burglary, etc.). The two variables that capture economic conditions in New York City are the New York City unemployment rate (UR), and the real minimum wage (RMINW). The arrest rate (arrests per crime) is a standard measure of deterrence. However, it is well-known that the use of the arrest rate as an explanatory variable creates biased estimates. This is because crime, which is the dependent variable, appears in the denominator of the arrest rate as an explanatory variable. Potential solutions are to deflate the arrests by population, or to substantially lag the arrest rate (Levitt 1998a; Mustard, forthcoming). In our case, none of these strategies is feasible because population figures are not available, and it is unclear exactly how many lags to impose with high frequency data we employ.

\footnotetext{
9 In models that use panel data with annual frequency the arrest rate is typically lagged one year (Mustard forthcoming, Mocan and Gittings 2002, Levitt 1998a).
} 
Therefore, following Corman and Mocan (2000), we use arrests (ARR) as an explanatory variable, but convert the estimated arrest elasticity of crime to the arrest rate elasticity of crime, as explained in the results section.

PRIS stands for the number of New York City residents incarcerated in state correctional facilities. POL is the size of the New York City police force. Adding police to the model in addition to felony and misdemeanor arrests allows us to investigate whether police presence has an additional impact on crime, after controlling for their actions. MISARR stands for the number of misdemeanor arrests. This variable allows for the test of validity of the broken windows hypothesis; that is, if broken windows hypothesis has merit, then after controlling for economic conditions and deterrence measures (including crime-specific arrests), an increase in misdemeanor arrests should have a negative impact on crime.

To control for the impact of changing demographics on crime we include the number of 14-to-17 year olds in New York City (TEENS). SEAS represents a vector of 11 monthly dichotomous variables to control for the impact of seasonality on crime.

The use of monthly data allows us to address the simultaneity between crime and deterrence. Following Corman and Mocan (2000), in Equation (1) $\mathrm{j} \geq 1, \mathrm{k} \geq 1, \mathrm{n} \geq 1, \mathrm{~m} \geq 1$. Put differently, it is postulated that the number of crimes committed in month $t$ depends on the past dynamics of the same criminal activity, the past values of arrests for that crime, and the past values of the misdemeanor arrests and incarcerations. These variables are lagged one month to avoid reverse causality from crime. On the other hand, $\mathrm{q} \geq 0, \mathrm{r} \geq 0, \mathrm{p} \geq 0, \mathrm{~s} \geq 0$; that is the contemporaneous values of the unemployment rate, the minimum wage, teens, and police are included. This means that, variations in crime 
cannot impact the current values of these variables. This is obvious for monthly data regarding economic and demographic variables; and it also applies to police because as explained in Corman and Mocan (2000), it takes at least six months to increase the size of the police force. Thus, an increase in crime in a given month cannot generate an increase in the police force in the same month.

\section{Data}

The data are compiled from a number of different sources. Crime and arrest data were obtained from the Crime Analysis Unit of the New York City Police Department. Monthly crime data are available between 1970 and 1999. The five FBI index crimes (murder, assault, robbery, burglary and motor vehicle theft) in New York City during this time period are displayed in Figures 1-5. 11 Crimes are measured as reported complaints. Murders, motor vehicle thefts, and assaults reached their maximum in either 1989 or 1990, and all crimes declined substantially since 1990, reaching their minimum in 1999. Later in the paper we investigate the extent to which our models explain the decline in crime between 1990 and 1999. Arrests for these crimes are displayed in Figures 6-10. They remain stable or decline between 1990 and 1999, which is not surprising because

\footnotetext{
${ }^{10}$ If an increase in arrests in a given month influences crimes in that same month through the incapacitation effect, lagging arrests by one month would be a specification error. However, Levitt (1998b) and Corman and Mocan (2000) demonstrated that the incapacitation effect is insignificant.

${ }^{11}$ We excluded rapes and grand larceny. The former crime was excluded because there is good reason to believe that reporting rates for these crimes varied significantly over the thirty-year period. Grand larceny was excluded because both the nominal and real value of the crime changed over the thirty-year period. The five crimes included in this analysis are believed to more consistent in their nature and reporting over the thirty year period.
} 
crimes declined during the same period. Arrest rates (arrests per crime) increase over the same time period.

We include misdemeanor arrests in the analysis to capture the changing nature of policing policies during the 1990 's, related to the "broken windows" hypothesis. Misdemeanor arrests pertain to arrests made for crimes such as petit larceny, assault in the third degree, prostitution, criminal mischief, and theft of services. Figure 11 shows that misdemeanor arrests fell in the early 1970's, rose somewhat in the early 1980's, and then experienced a large, sustained increase around 1994.

It is difficult to find a single, consistent measure of the overall economic health of New York City and its residents. We use the unemployment rate and the real minimum wage as measures of economic conditions in New York City. Each of these indicators measures a different aspect of the economy; therefore each has a different pattern over the three decades. ${ }^{13}$ Figure 12 presents the real minimum wage in New York City, computed as the New York State or Federal (whichever was higher) minimum wage, and adjusted for inflation, using the New York City Consumer Price Index (base year=1982$84) . \frac{14}{}$ After a sustained erosion in the value of the minimum wage in 1980 s, there were two nominal wage increases in 1990 and 1991; and two other increases were implemented in 1996 and 1997. Overall, the real minimum wage remained rather stable during the 1990s. Figure 13 displays the City's unemployment rate, which reached double-digit levels for sustained periods during both the mid-1970's and the early 1990's.

\footnotetext{
${ }^{12}$ The arrest rates are displayed in Appendix Figures A1- A5.

${ }^{13}$ In the sensitivity analysis section we report results from the models where total recipients of public assistance is employed instead of the unemployment rate.

${ }^{14}$ Minimum wage data was obtained from the State of New York Department of Labor, Division of Research and Statistics, and Consumer Price Index data was obtained from the US Department of Labor's Bureau of Labor Statistics.
} 
According to the unemployment rate, economic conditions were worse toward the earlyto mid-1990's and improved in the latter half of that decade. ${ }^{15}$

Figure 14 presents the number of uniformed officers at all ranks. In April of 1995, the Transit Police were merged with the NYPD, and in May, the Housing Police were added. In order to account for this merger, and to have a consistent series, we subtracted the Transit and Housing police from the total number of officers after April 1995. $\frac{16}{}$ The size of the police force varied considerably over the three decades under consideration. In 1970, there were around 32,000 uniformed officers in the New York Police Department. In conjunction with New York City's 1970's fiscal crisis, the number of officers fell dramatically between 1970 and 1980, attaining a annual low point in 1980 --a drop of almost $30 \%$. Since 1980 , the overall trend has been one of growth in the number of officers, ending in 1999 with almost 35,000. This represents a quite modest change from the original level in 1970, but it is a dramatic (more than 50\%) increase from its lowest level in 1980.

Data sources allow an annual count of prison inmates from New York City who are in State Correctional Facilities from December of 1974 through December of 1988. We interpolated the monthly figures from the annual ones up to January 1988, when prison population data began to be recorded monthly. As Figure 15 demonstrates, the prison population from New York City grew through most of the sample period, then leveled off during the last half of the 1990's.

\footnotetext{
${ }^{15}$ These data were obtained from the US Department of Labor's Bureau of Labor Statistics.

${ }^{16}$ We have subtracted, rather than added because we were not able to obtain separate Transit and Housing Police numbers, beginning in January of 1970. Police data were obtained from the Office of Management and Planning at the New York City Police Department.

${ }^{17}$ Prison population data were obtained from the Independent Budget Office of New York City.
} 
Consideration of the population's demographic composition is important;

however, most demographic data rely on the decennial censuses, with yearly values interpolated in-between. Rather than using Census-based data, we proxy the number of teens by summing the number of students entering ninth grade in the current year plus in the previous three years in both public and private schools in New York City. ${ }^{18}$ Because we only have September counts for each year, we used the Hodrick-Prescott filter to obtain the trend of the data (Figure 16), which is employed in empirical analysis. 19

V. Empirical Implementation and the Results

Following Corman and Mocan (2000), Mocan (1999) and the literature they cite, we applied unit root tests to investigate the trend behavior of the variables using standard augmented Dickey-Fuller tests. The results, displayed in Appendix Table A-1, provide evidence for unit roots (stochastic trends) in all variables except for the prison population and teen population. This means that the proper specification of Equation (1) should involve regressing the first difference of crime variables on the first difference of the right-hand variables with unit roots and should not include a time trend as a regressor. 20 Co-integration tests, which are also displayed in Appendix Table A-1 suggest that there is

\footnotetext{
${ }^{18}$ If arrests are a good proxy for crime commission, then this group commits more crimes per capita than 18 to 20 year olds or those 21 and over. Data were obtained from the Independent Budget Office of New York City.

${ }^{19}$ We used the Hodrick-Prescott filter (Hodrick and Prescott, 1997) to obtain the slowly evolving trend component. In this procedure, the trend component in the variable under investigation, $\Gamma$, is obtained by solving the following convex minimization problem.

$\min \sum_{t=1}^{T}\left(X_{t}-\Gamma_{t}\right)^{2}+\lambda \sum_{t=1}^{T}\left(X_{t}-2 \Gamma_{t-1}+\Gamma_{t-2}\right)^{2}$ where $\mathrm{X}$ is the variable of interest, and $\lambda$ is the weight on squared second difference of growth component, which penalizes acceleration in the trend. Following previous examples (e.g., Blackburn and Ravn, 1992; Mocan, 1999), $\lambda$ is set to be 1,600, but the decomposition was not sensitive to the variations in the value of $\lambda$.
} 
evidence of co-integration between crime, and the right-hand variables in all cases, indicating that the estimated regressions should include an error correction term. This means that even though crime and its determinants are governed by random trends, there exists an equilibrium relationship between them, which keeps them together in the longrun.

The lag length of each variable is determined by Akaike Information Criterion (AIC). The natural logarithms of the variables are taken before differencing, and estimations are carried out using a heteroscedasticity and serial correlation robust covariance matrix with serial correlation up to lag twenty-four.

Table 1 displays a summary of the results of the estimation of equation (1) for the five different crimes. It reports summed coefficients along with standard errors. ${ }_{1}$ The sum of the coefficients represents the long-run impact of the explanatory variables on crime. The numbers in parentheses after variables represent the range of the lag length. For example, ARRESTS (1-5) in the murder regression indicates that murders are influenced by five past values of murder arrests as determined by AIC. The sensitivity of the results to alternative lag lengths is discussed below. Because the prison population variable was measured beginning in December of 1974, regressions span from December of 1974 through December of 1999. The full results appear in Appendix Tables A-2 through A-6.

As Table 1 demonstrates, felony arrests have a negative and statistically significant impact on all five index crimes analyzed. An increase in prison inmates from

\footnotetext{
${ }^{20}$ The teen population variable and the prison variable do not contain unit roots, and therefore these variables enter the models in levels rather than first differences.

${ }^{21}$ Because the summed coefficients of teen population were never significant, they are not reported in Table 1 .
} 
New York has a negative impact on all crimes but assault. Controlling for other measures of deterrence, the size of the police force has an impact on motor vehicle thefts only.

Misdemeanor arrests have a significant negative impact on robbery and motor vehicle theft. This indicates that, holding constant their own arrests, the size of the police force and prison population, the growth rates in robberies and motor vehicle thefts decline as the growth rate of misdemeanor arrests increases. This result provides support for the broken windows hypothesis in case of these two crimes.

It can be argued that the impact of misdemeanor arrests on robbery and motor vehicle theft is observed because of an incapacitation effect. However, there is evidence that, for most misdemeanor arrests, incarcerations occur in a small minority of cases and tend to be short-term. Nelson (1991) studied misdemeanor arrests for individuals in New York State occurring between January 1, 1985 and December 31, 1986.2 During this period, the total number of misdemeanor arrests for the largest 4 counties in New York City (excluding Richmond) was 122, 797. Of these arrests, 9.4\% resulted in a conviction with a jail sentence. For those sentenced to a jail term, the average length of stay was 27.5 days. Thus, the expected jail sentence given misdemeanor arrest was 2.6 days. 3.3

\footnotetext{
${ }^{22}$ Nelson (1991) examined the first arrest during the period for any individual, and only lower court processing, since almost all persons arrested for misdemeanor charges were disposed in the lower courts. The study excluded prostitution and DWI arrests. There is specific information for four out of five New York City counties: NY, Kings (Brooklyn), Queens, and Bronx. Richmond (Staten Island) is not reported as a separate county, and is, therefore, excluded from these results.

${ }^{23}$ Note that this number will be considerably lower than the expected incarceration for those convicted of a misdemeanor or the expected incarceration for those in jail. This is because many individuals arrested for more serious (felony) crimes are convicted of lesser offenses and/or are sentenced to jail terms (rather than prison). In a study of felony case processing in New York between 1990 and 1992, Nelson (1995) found that individuals convicted of a felony were more likely to be sent to jail than sent to prison, and about $40 \%$ of those who were arrested for a felony and were convicted, had been convicted (most likely pleabargained) of a misdemeanor offense.
} 
Some defendants who were convicted of a misdemeanor offense received a sentence of "time served". This means that they spent some time in jail prior to their conviction. Approximately $13 \%$ of those arrested for a misdemeanor received sentences of "time served". The average time between arrest and arraignment for December of that year was slightly over 24 hours, down from the 40 hours in 1989 (Cooper 1996). This information indicates that misdemeanor arrests would result in negligible incarceration effects for most offenders. Therefore, it is unlikely that the impact of misdemeanor arrests on robbery and motor vehicle theft is due to incapacitation.

Increases in the real minimum wage are found to significantly reduce robberies and murders, and higher unemployment is significantly related to more burglaries and motor vehicle thefts. Thus, although it is not always the same economic indicator, there is evidence that economic conditions impact all felony crimes except assaults. 24

\section{Magnitudes}

To assess the magnitudes of the effects of each variable on crime, we used the sum of the coefficients reported in Table 1, and calculated the elasticities of own arrest rates, misdemeanor arrests, prison population, the unemployment rate, and the real minimum wage. The calculated elasticities are reported in Table 2. Note that we have converted the results from number of felony arrests to the arrest rate, to allow our results to be compared with similar elasticity estimates.

\footnotetext{
${ }^{24}$ Although the estimated models include a large number of deterrence variables, there are other potentially important variables such as the conviction rates which are not included. Mustard (forthcoming) shows that conviction rates are negatively correlated with arrest rates, which suggests that the true impact of the arrest rates may be larger than those reported here.

${ }^{25}$ We calculate the elasticity of crime with respect to the arrest rate as follows: ARRT=AR/CR, where ARRT is the arrest rate, AR represents the number of arrests, and CR stands for crime. That means that
} 
Table 2 includes elasticities only for statistically significant variables. The first row in each cell reports the elasticity calculated using a zero-growth steady-state scenario for the variables in the system. The elasticities reported in the second row are calculated using the average of the year-to-year growth rates of the explanatory variables. Table 2 demonstrates, for example, that a 10 percent increase in the murder arrest rate generates about a four percent reduction in murders, and a 10 percent increase in the real minimum wage results in a 6.3 to 6.9 percent decrease in murders.

Robberies and motor vehicle thefts are more responsive to changes in their arrest rates than are murder, burglary, and assault. Also, robberies and motor vehicle thefts are impacted by misdemeanor arrests. A 10 percent increase in misdemeanor arrests generates 1.6 to 2.1 percent decline in motor vehicle thefts and 2.5 to 3.2 percent decline in robberies.

The average unemployment rate between 1974 and 1999 was 8 percent in New York City. Using the unemployment rate elasticities reported in Table 2, this means that a one-percentage point decline in the unemployment rate (a $12.5 \%$ decline) generates about a 2.2 percent decline in burglaries and 1.8 percent decline in motor-vehicle thefts. These magnitudes are remarkably similar to those reported by Gould, Mustard and Weinberg (2002), and Freeman and Rodgers (2000).

The mean values for arrest rates are $65.6 \%$ for murder, $56 \%$ for assault, $9.5 \%$ for burglary, $24.2 \%$ for robbery and $8.6 \%$ for motor vehicle theft. Thus, a one percentage point increase in their respective arrest rates would generate the following declines: $0.6 \%$

$\ln (\mathrm{ARRT})=\ln (\mathrm{AR})-\ln (\mathrm{CR})$, and $\partial \ln (\mathrm{ARRT}) / \partial \ln (\mathrm{CR})=\partial \ln (\mathrm{AR}) / \partial \ln (\mathrm{CR})-1$. Let $\mathrm{E}$ denote the elasticity of crime with respect to its own arrest rate, and let $\mathrm{K}$ represent the elasticity of crime with respect to arrests. Then, $\mathrm{E}=\mathrm{K} /(1-\mathrm{K})$. 
decline in murder, $0.4 \%$ decline in assault, $3.1 \%$ decline in burglary, $2.4 \%$ decline in robbery, and 5.9\% decline in motor vehicle theft.

Although prison population is statistically significantly related to four of the crimes, the magnitudes of the elasticities are low, ranging from -0.03 to -0.08 . Marvel and Moody (1994) reported similarly low incapacitation elasticities for violent crimes, where their elasticity for all index crimes was -0.16 . Levitt (1996) estimated larger incapacitation elasticities, although Donohue and Siegelman (1998) argue that these elasticities may be too high. Using the same algorithm employed by Marvell and Moody (1994) to adjust for reporting rate, ${ }^{6}$ we find that a 10 percent increase in NYC residents who are in state prisons generates 962 fewer burglaries, 365 fewer robberies, 11 fewer murders, and 336 fewer motor vehicle thefts per year.

\section{Sensitivity Analysis}

To investigate the robustness of the results we performed a number of exercises. First, we subtracted drug related misdemeanor arrests from total misdemeanor arrests, and obtained total non-drug misdemeanor arrests. The time-series behavior of this measure is is shown in Appendix Figure A-6. Using this measure of misdemeanor arrests, we obtained very similar results. Second, we replaced the unemployment rate with total recipients of public assistance in New York City. ${ }^{27}$ The results remain unchanged, and an increase in total recipients was positively related to robberies and motor vehicle thefts. Finally, we experimented with alternative lag lengths. The lag lengths of the models

\footnotetext{
${ }^{26}$ Following Marvell and Moody (1994) we used the crime-specific reporting rates from 2000 Crime Victimization Survey to adjust the number of crimes averted.

${ }^{27}$ These numbers were obtained from the Office of Data Analysis and Research of the New York City Human Resources Administration. Public Assistance Recipients include those receiving Family Assistance Program (FAP, formerly under the AFDC program) and those receiving Safety Net Assistance (SNA, formerly under the Home Relief program). Note that the welfare programs were changed by the New York State Welfare Reform Act of 1997.
} 
presented in Table 1 were determined by Akaike Information Criterion, which indicated different lag lengths for explanatory variables. In this exercise we imposed the same lag length to each variable, and tried lag lengths of 3, 6, 9 and 12. The results, shown in the Appendix Table A-7, are reasonably consistent with those obtained from the earlier ones, although there is some sensitivity pertaining to misdemeanor arrest. For example, misdemeanor arrests have a negative and significant effect in some lag length specifications for murder and burglary, and it is positive in assault, whereas it was not significant in the original models for these crimes.

\section{What accounted for the large drops in felony crimes in New York City in the 1990's?}

To put these results into perspective, we examined the impact of each of our variables in reducing felony crime in New York City in the 1990s. Using the elasticity estimates reported in Table 2 and the actual percentage changes in the deterrence and economic variables between 1990 and 1999, we calculated the percent change in the number of crimes between 1990 and 1999 attributable to each variable. The results are presented in Table 3. Felony arrest rates (except for motor vehicle thefts) increased dramatically during the 1990 s, with a range of about $50 \%$ to $70 \%$. Similarly, misdemeanor arrests increased over $70 \% .28$ The size of the police force increased about $35 \%$ during the same period, and the number of imprisoned New York City residents also experienced a substantial increase during this period as well (24\%). Economic variables did not experience the same magnitude of change as the criminal justice variables. The

\footnotetext{
${ }^{28}$ The increase is measured as the percentage change between the 12-month average in 1990 and the 12 month average in 1999.
} 
unemployment rate declined three percent and real minimum wage rose 12 percent between 1990 and 1999.

As depicted in Table 3, the model is able to explain a sizable fraction of the actual drop in the number of felony crimes in New York City during the 1990's. For example, the actual drop in murders between 1990 and 1999 is 73 percent. Our model suggests that the observed increase in the murder arrest rate accounts for 29 percent of this decline. Increased prison population accounts for 2 percent of the decline in murders, and the increase in the real minimum wage explains 8 percent of this drop. Thus, these three factors together predict a 39 percent decline in murders between 1990 and 1999. The actual decline is 73 percent; thus we are able to explain 53 percent of the drop in murders between 1990 and 1999 (39 percent of the observed 73 percent decline). Similarly, arrests, police, prison population, and economic variables account for the 86 percent of the actual drop in robberies, and between a third and a half of the drop in burglaries and motor vehicle thefts. As Table 3 demonstrates, the primary reason for the drop in felony crimes in the decade of the 1990's is due to felony arrests, and misdemeanor arrests. Although prison population and economic variables were found to be significant, their impact is not as large. Increased police presence accounts for 20 percent of the decline in motor vehicle thefts, but has no direct influence on other crimes.

The reason for the weak impact on economic variables is that their elasticities are relatively smaller and the actual change in the unemployment and minimum wage in 1990s was not big enough to generate a large impact on crime. ${ }^{29}$ For example, the minimum wage increased from an average of 2.77 in 1990 to 3.09 in 1999, which is a 12 
percent increase. The mean value of real minimum wage was $\$ 3.86$ in the first half of the

1970s. Had the real minimum wage been increased to that level from1990 to 1999, its impact on the decline in robberies would have been 14 percent, and its impact on the decline in murders would have been 26 percent.

\section{Summary}

While the U.S. crime rates declined in the last decade, the reverse is true for most European Union countries (Barclay, Tavares and Siddique 2001, Pfeiffer 1998, Vinocur 2002). In both cases, scholars and policy makers try to understand the relative importance of economics factors and deterrence measures on criminal activity. For example, it has been debated whether the remarkable decline in criminal activity in New York City between 1990 and 1999 is attributable to "get tough" policies or to improved economic conditions. $\frac{11}{1}$ Similarly, the relative impacts of police, prisons, and [social] disadvantage on crime have been questioned by Britain's Home Office Minister Paul Boateng (CNN World 2001), and French Prime Minister Lionel Jospin Jospin has reassessed the relative importance of social conditions, alone, in combatting crime, where

\footnotetext{
${ }^{29}$ Most accounts of drug usage in New York City indicate that the rise of cocaine-related drug use in the early 1990s was more dramatic than the subsequent decline later in the decade, so that cocaine drug usage increased from 1990 to 1999. Thus, a dramatic drop in drug usage could not account for the drop in crime. ${ }^{30}$ Also, if we were to select 1994 to 1999 as the comparison years for unemployment, the unemployment rate in New York City fell by $30 \%$, and the drop in unemployment would have accounted for 5 to 6 percent of the drop in burglaries and motor vehicle thefts.

${ }^{31}$ Another potential explanation is legalized abortion. Donohue and Levitt (2001) show that legalized abortion had an impact on crime rates with a twenty-year lag. They find that crime was $15-25$ percent lower in 1997 in comparison to what would have been observed had abortion remained illegal. New York City liberalized its abortion law in July 1970. Joyce and Mocan (1990) show that legalization of abortion had a significant impact on adolescent childbearing in New York City. Thus, it is likely that some of the residual drop in observed crime in New York City (one which is not explained by our model) is attributable to legalized abortion.
} 
he stated that he was naïve to believe that his battle against unemployment would reduce crime (Nichols 2002).

In this paper we investigate the impacts of economic conditions (carrots) and sanctions (sticks) on murder, assault, robbery, burglary and motor vehicle theft in New York City. Carrots are measured by the unemployment rate and the real minimum wage. Sticks are measured by crime-specific arrests, size of the police force and the number of New York City residents in state prisons. In addition, we test the validity of the "broken windows" hypothesis, which asserts that by implementing policing strategies which signal that minor levels of criminal activity will not be ignored, criminals will be deterred from committing more serious crimes. The paper uses monthly time-series data from New York City spanning 1974-1999, and consistent with the statements of the Police Department and major Rudolph Guiliani, uses misdemeanor arrests as a measure of "broken windows" policing.

We find that own felony arrests deter all five crimes analyzed. The unemployment rate has an impact on burglary and motor vehicle theft, while real minimum wage has an impact on murder and robbery. An increase in the number of New York City residents in state correctional facilities reduces all crimes but assault, but the magnitude of the influence is not large.

Controlling for economic conditions and deterrence (real minimum wage, unemployment rate, felony arrests, prison population and the size of the police force), misdemeanor arrests have an impact on motor vehicle theft and robbery. A 10 percent increase in misdemeanor arrests decreases motor vehicle thefts by 1.6 to 2.1 percent and robberies by 2.5 to 3.2 percent. We do not find evidence to support the contention that 
broken windows policing strategy affects the other crimes.

Between 1990 and 1999 New York City experienced a 73 percent drop in homicide, a 66 percent drop in burglary, a 40 percent drop in assault. Robbery and motor vehicle theft declined by 67 percent and 73 percent, respectively, during the same period. Our models explain from about 33 to 86 percent of the observed decline in these crimes. While both economic and deterrence variables are important in explaining the decline in crime in New York City, the contribution of deterrence measures is larger than those of economic variables. 


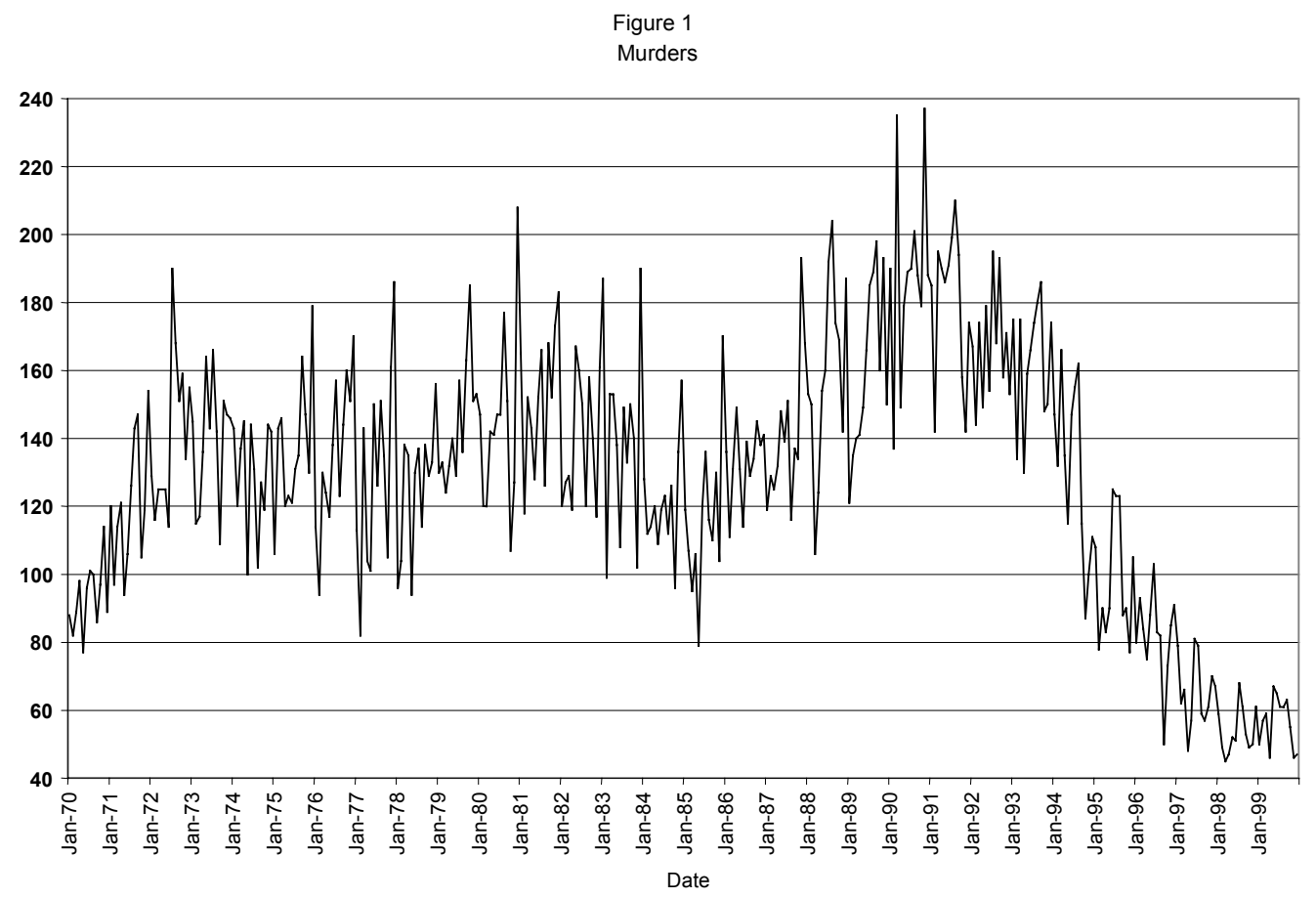

Figure 2

Burglaries

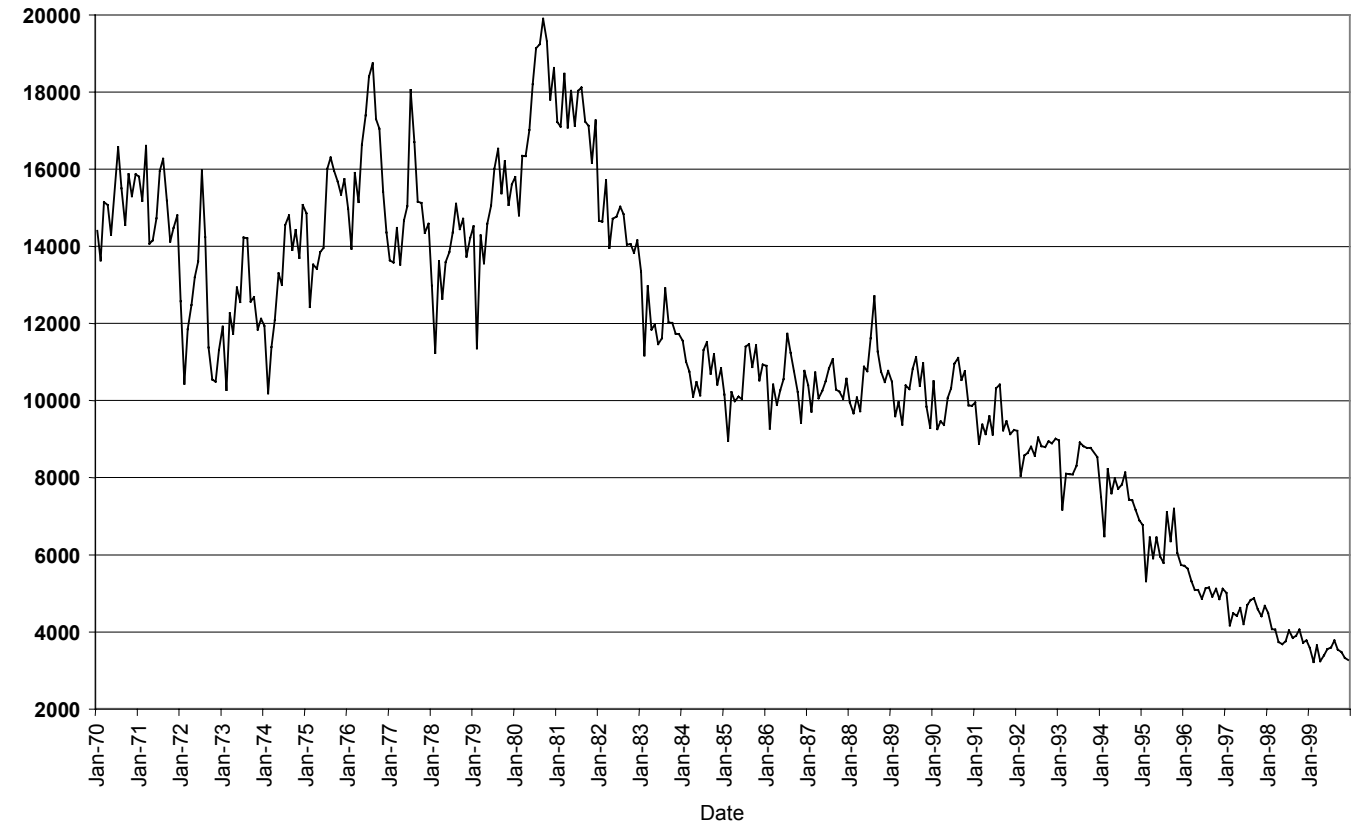


Figure 3

Felony Assaults

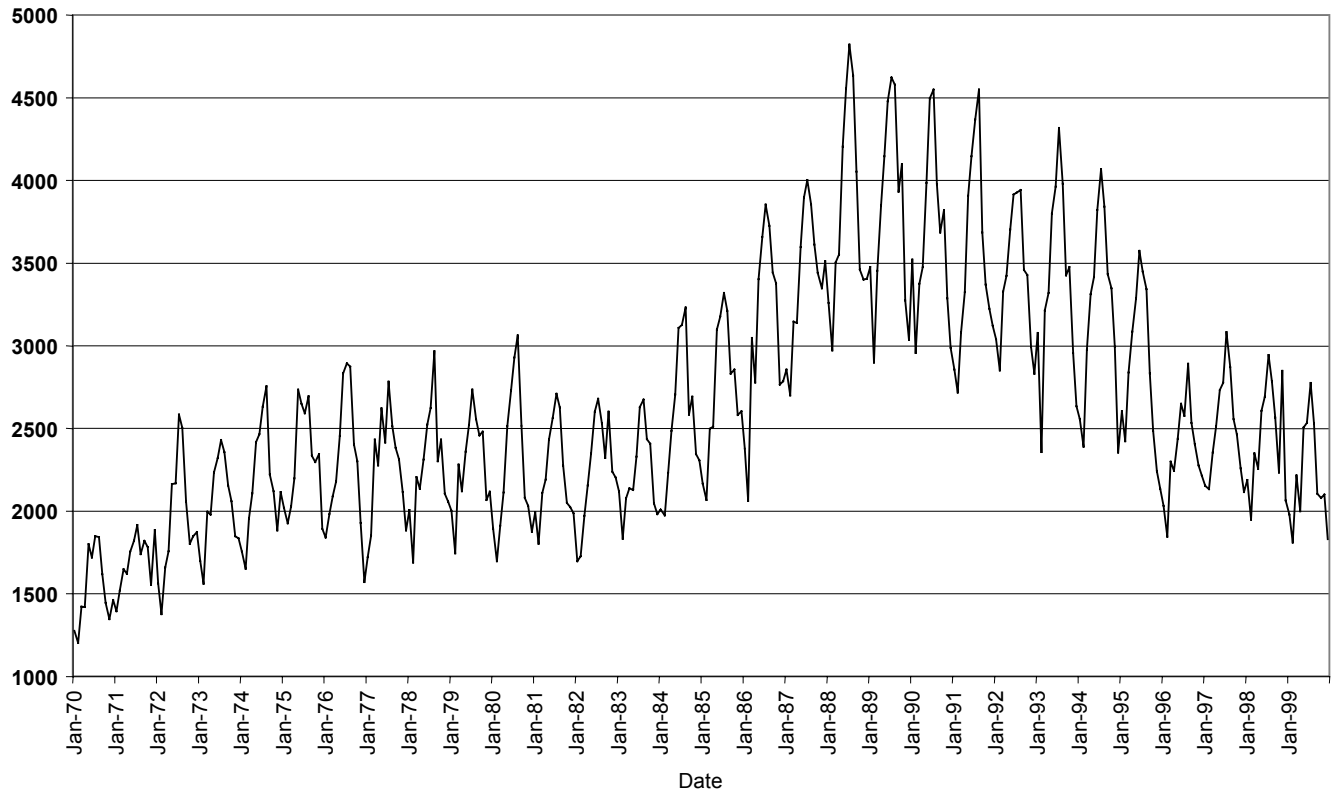

Figure 4

Robberies

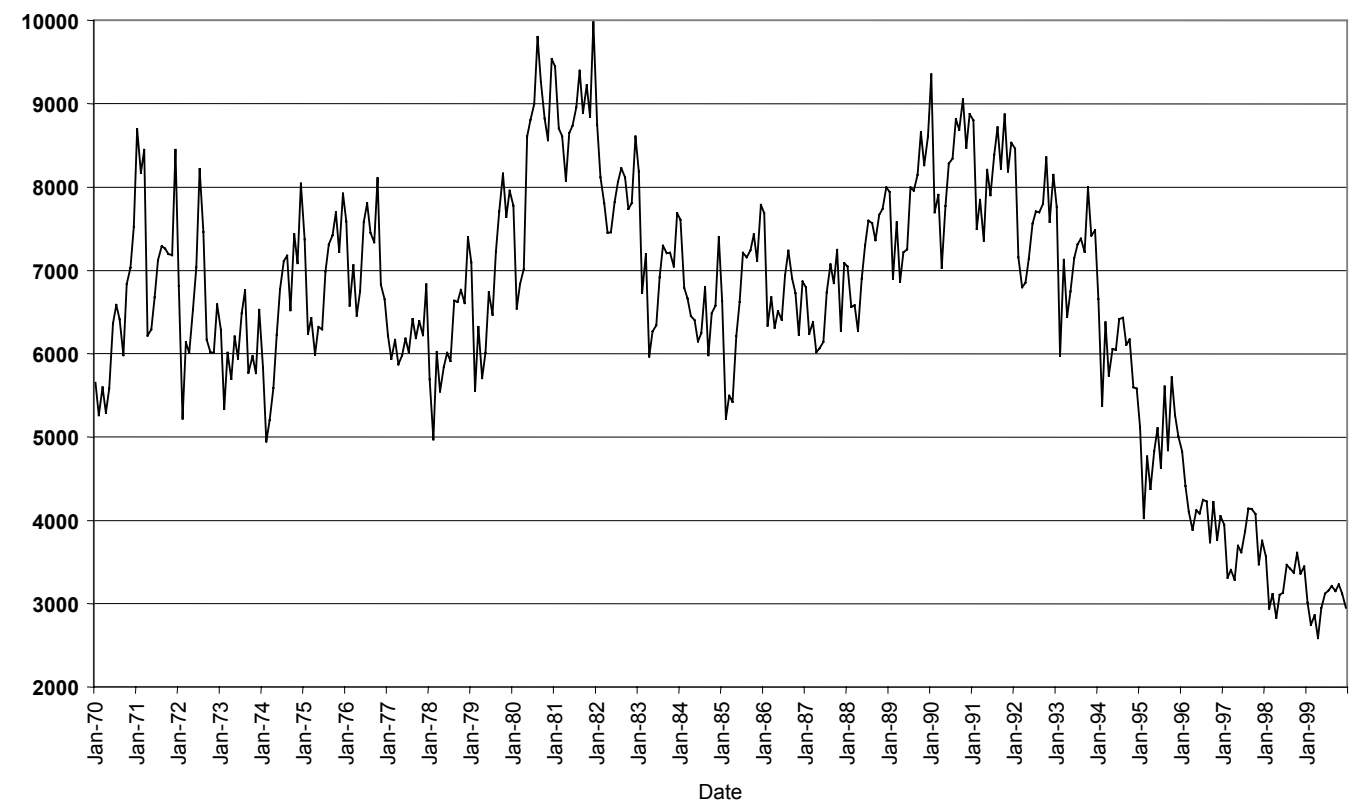



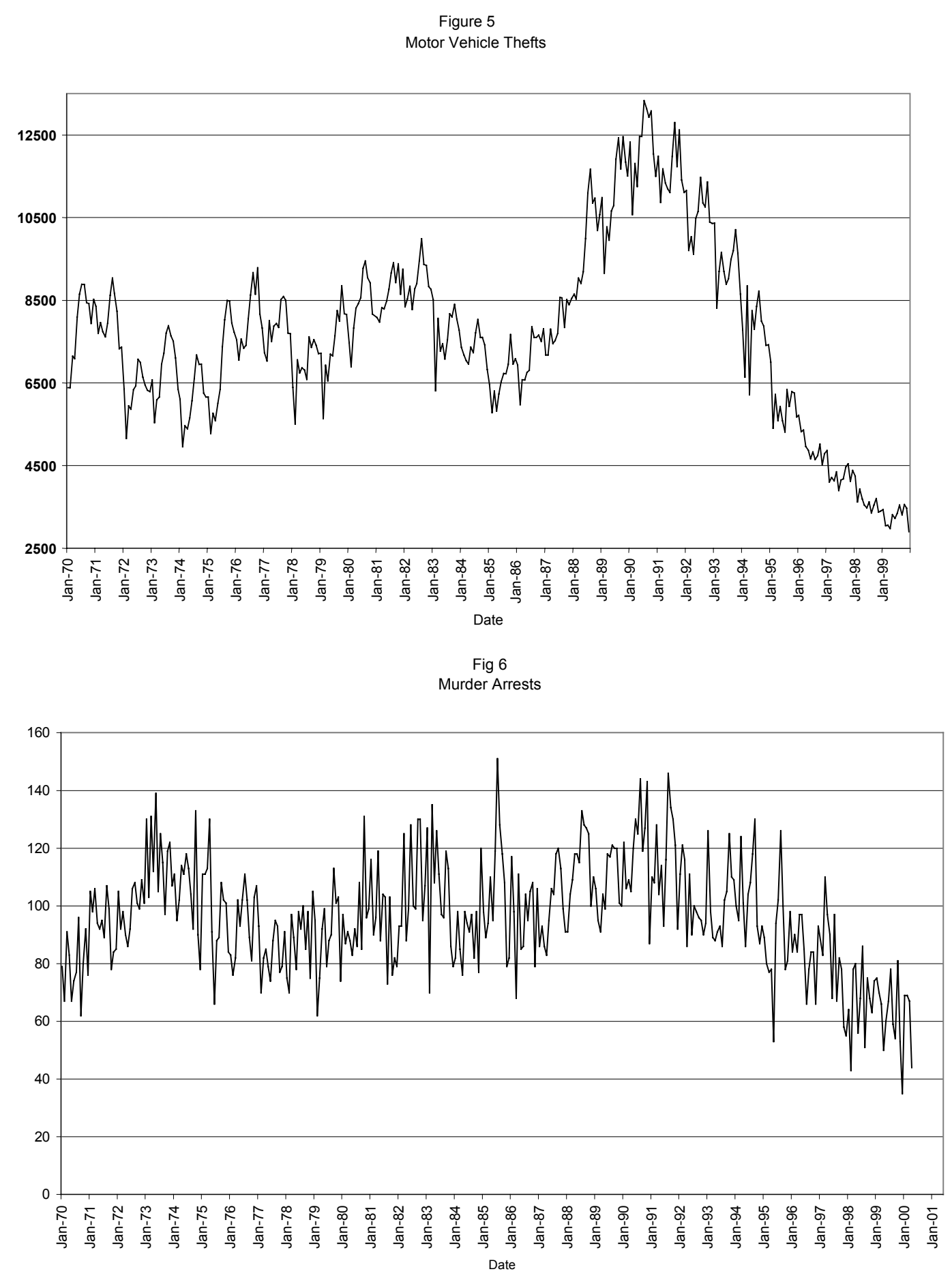

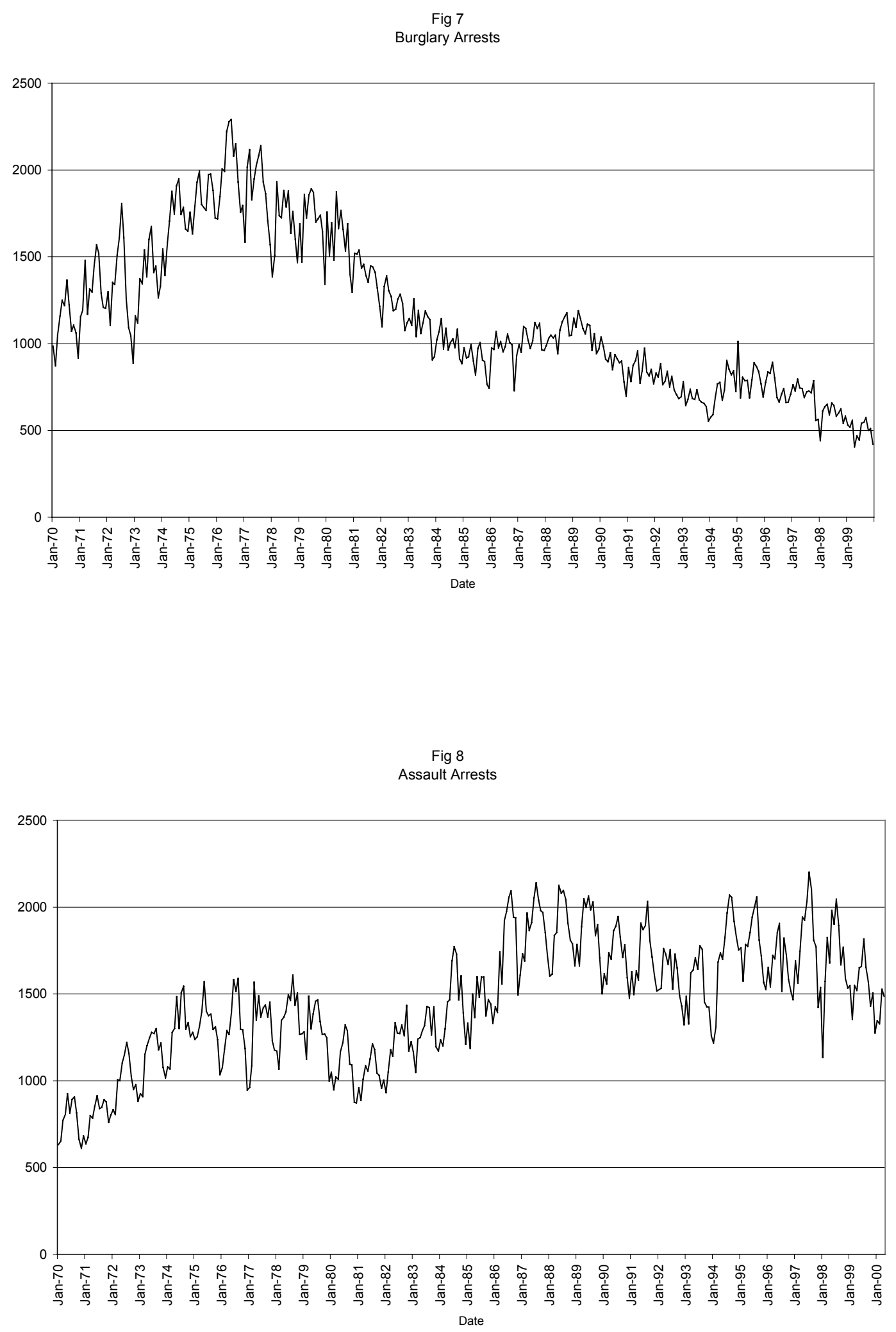
Fig 9

Robbery Arrests



Fig 10

Motor Vehicle Theft Arrests

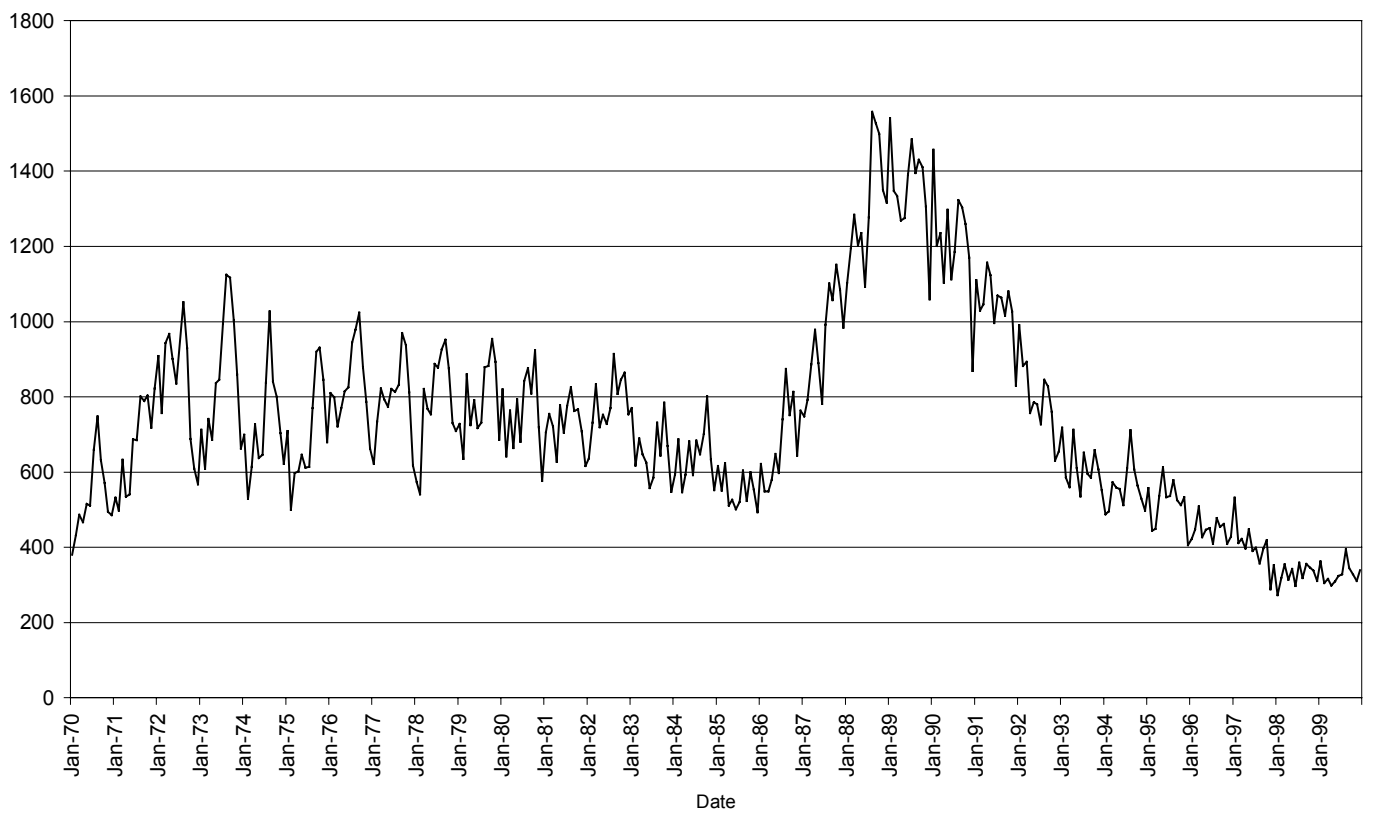


Figure 11

Total Misdemeanor Arrests



Figure 12

Real Minimum Wage in New York City

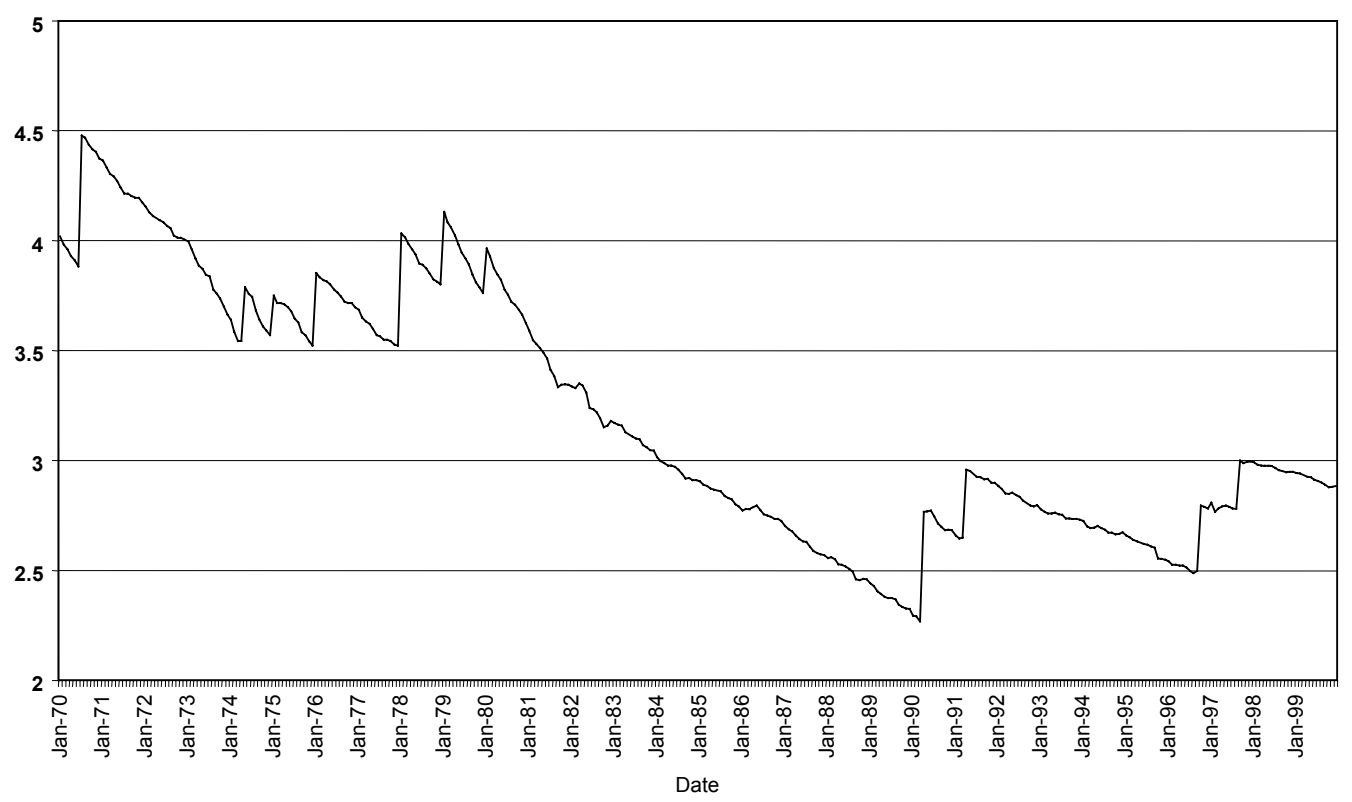


Figure 13

NYC Unemployment Rate

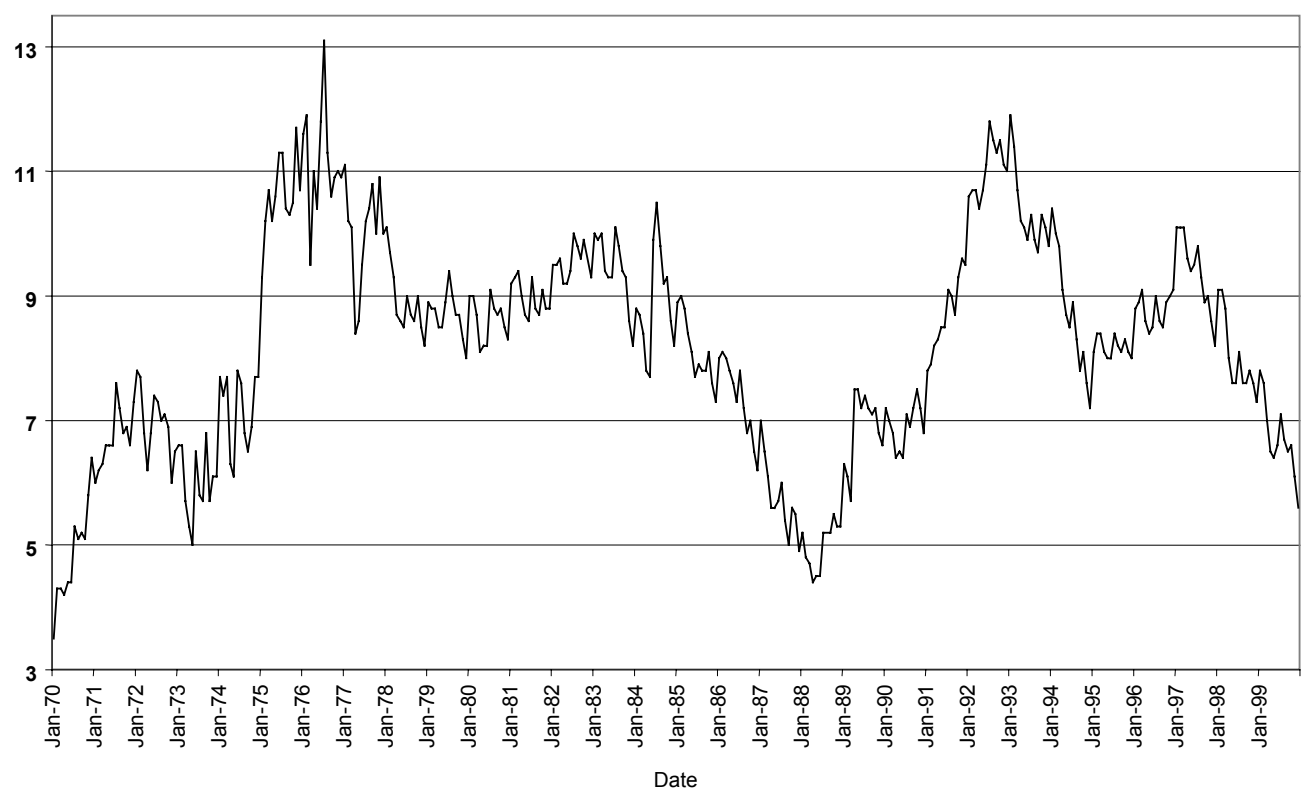

Figure 14

Number of Police (excluding transit \& housing police)

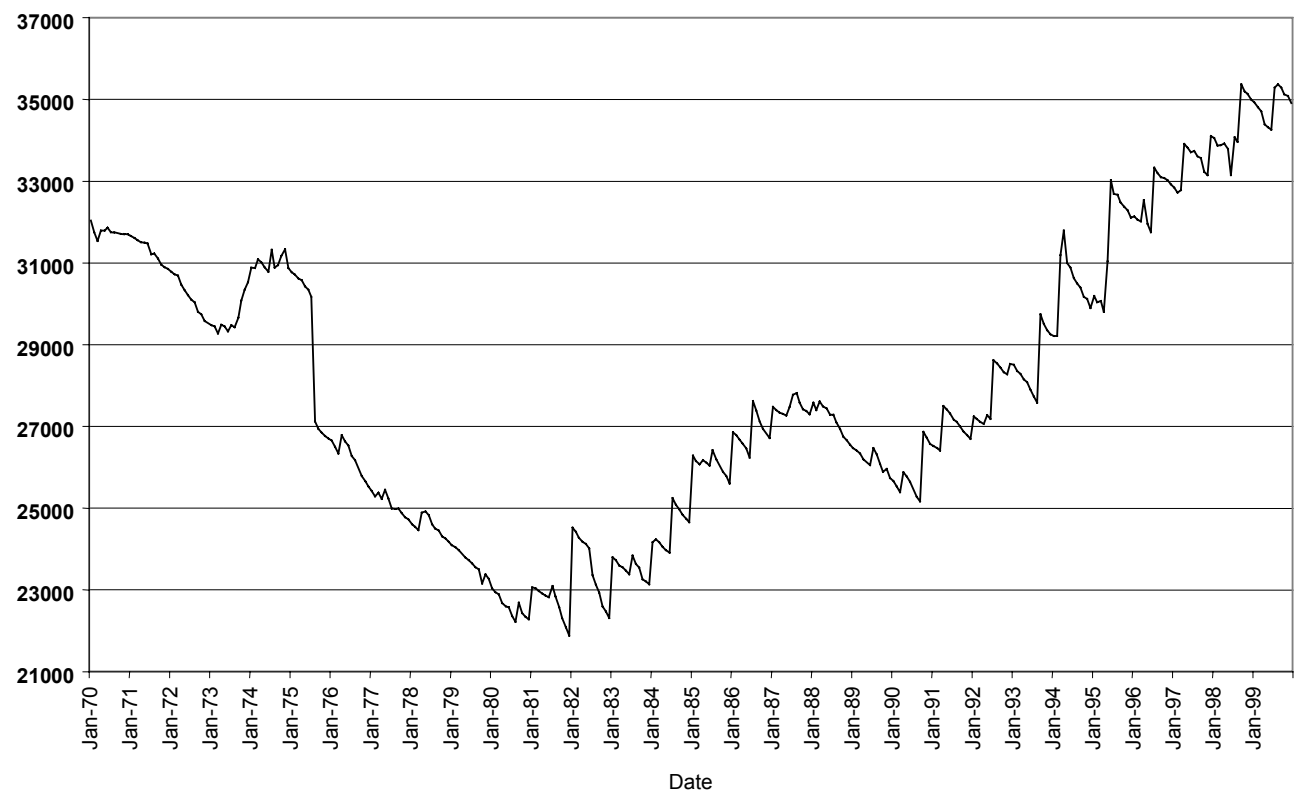


Figure 15

State Prison Population from NYC

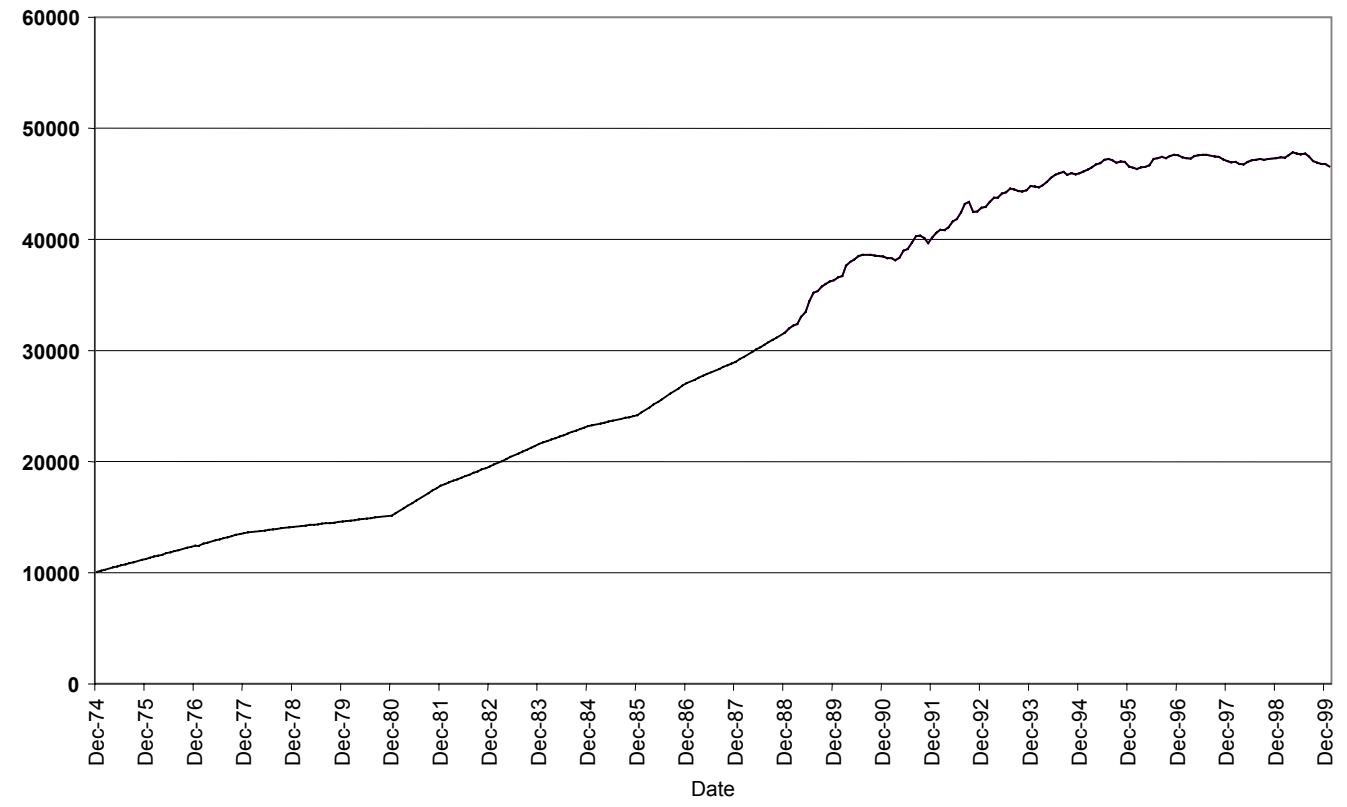

Figure 16

Actual and Smoothed Values of Youths Ages 14-17 in NYC

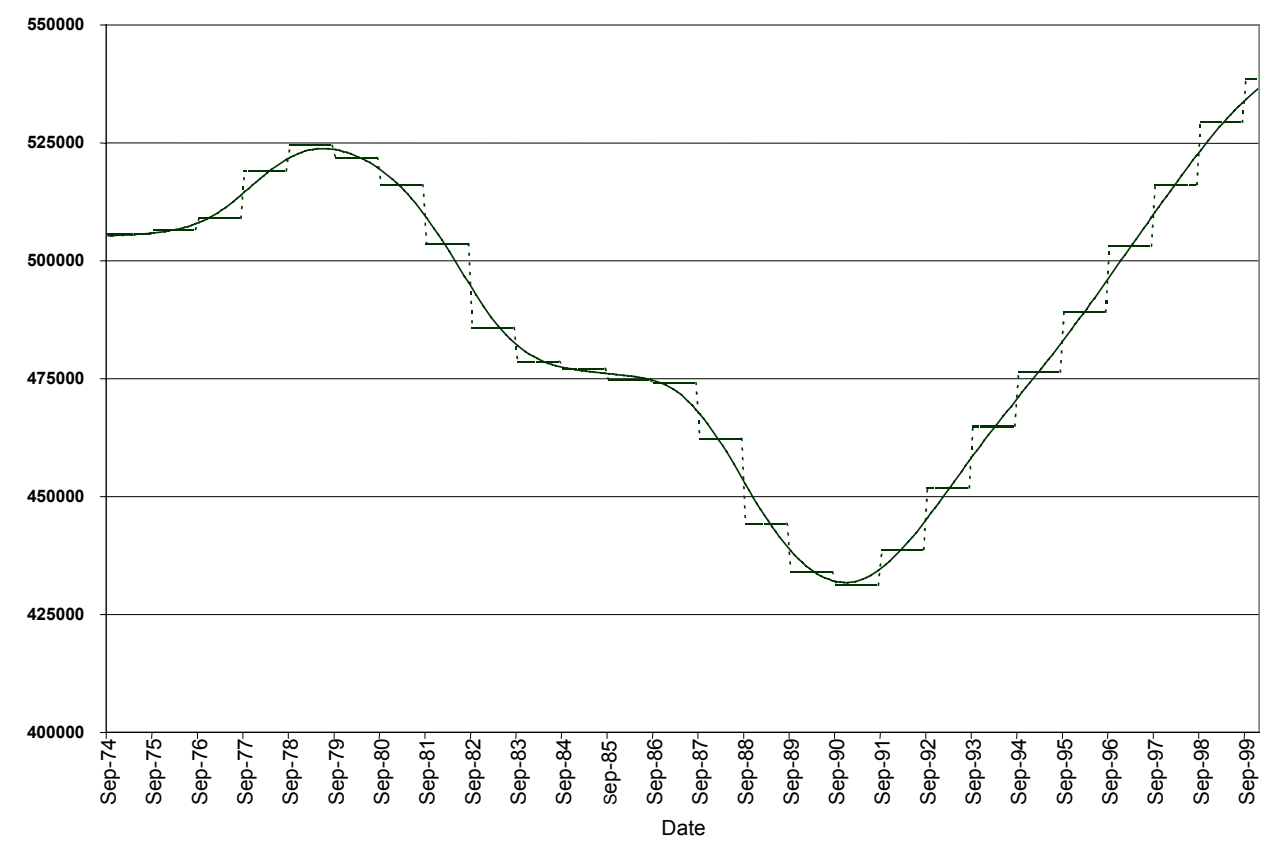


Table 1

Sum of the Coefficients

Coefficient

Std. Error

Murder

\section{ARRESTS (1-5)}

POLICE (0-2)

TOTAL MISD. ARRESTS (1-5)

PRISON POPULATION (1-8)

UNEMPLOYMENT (0-3)

NYC MINIMUM WAGE (0)

$\begin{array}{ll}-0.67^{* * *} & (0.229) \\ -0.468 & (1.214) \\ -0.629 & (0.395) \\ -0.077^{* *} & (0.036) \\ 0.273 & (0.329) \\ -0.692^{* *} & (0.297)\end{array}$

Burglary

$\begin{array}{lll}\text { ARRESTS (1-21) } & -0.466^{* *} & (0.212) \\ \text { POLICE (0-1) } & -0.235 & (0.259) \\ \text { TOTAL MISD. ARRESTS (1-2) } & -0.058 & (0.06) \\ \text { PRISON POPULATION (1-18) } & -0.057^{* * *} & (0.01) \\ \text { UNEMPLOYMENT }(0-2) & 0.164^{*} & (0.088) \\ \text { NYC MINIMUM WAGE }(0-2) & 0.328 & (0.325)\end{array}$

Assault

$\begin{array}{lll}\text { ARRESTS }(1-4) & -0.247^{*} & (0.145) \\ \text { POLICE (0-1) } & -0.028 & (0.247) \\ \text { TOTAL MISD. ARRESTS (1-2) } & 0.075 & (0.086) \\ \text { PRISON POPULATION }(1-5) & -0.007 & (0.015) \\ \text { UNEMPLOYMENT }(0-1) & 0.078 & (0.124) \\ \text { NYC MINIMUM WAGE }(0-1) & 0.182 & (0.202)\end{array}$

Robbery

$\begin{array}{lll}\text { ARRESTS }(1-12) & -1.31^{* * *} & (0.344) \\ \text { POLICE }(0-2) & -0.364 & (0.454) \\ \text { TOTAL MISD. ARRESTS }(1-2) & -0.25^{* * *} & (0.049) \\ \text { PRISON POPULATION }(1-11) & -0.028^{*} & (0.015) \\ \text { UNEMPLOYMENT }(0-2) & -0.148 & (0.099) \\ \text { NYC MINIMUM WAGE }(0-1) & -0.373^{*} & (0.21)\end{array}$

Motor Vehicle Theft

$\begin{array}{lll}\text { ARRESTS (1-14) } & -1.042^{* * *} & (0.272) \\ \text { POLICE (0-2) } & -0.563^{* *} & (0.28) \\ \text { TOTAL MISD. ARRESTS (1-2) } & -0.156^{* *} & (0.068) \\ \text { PRISON POPULATION }(1-8) & -0.027^{* * *} & (0.01) \\ \text { UNEMPLOYMENT }(0) & 0.125^{* *} & (0.049) \\ \text { NYC MINIMUM WAGE }(0-2) & -0.254 & (0.323)\end{array}$

Note: $* * *$, or $* * *$ signify statistical significance at the $10 \%, 5 \%$, and $1 \%$ levels, respectively. 
Table 2

Elasticity Estimates

\begin{tabular}{|l|l|l|l|l|l|}
\hline $\begin{array}{l}\text { Explanatory } \\
\text { Variable }\end{array}$ & Murder & Assault & Burglary & Robbery & $\begin{array}{l}\text { Motor Vehicle } \\
\text { Theft }\end{array}$ \\
\hline (Own) Felony Arrest & -0.40 & -0.20 & -0.32 & -0.57 & -0.51 \\
Rate & -0.39 & -0.24 & -0.27 & -0.59 & -0.50 \\
\hline $\begin{array}{l}\text { Total Misdemeanor } \\
\text { Arrests }\end{array}$ & & & & -0.25 & -0.16 \\
\hline Police & & & & -0.32 & -0.21 \\
\hline Unemployment Rate & & & 0.16 & & -0.56 \\
& & & 0.19 & & -0.59 \\
\hline Real Min. Wage & -0.69 & & & -0.37 & 0.13 \\
& -0.63 & & & -0.34 & \\
\hline Prison & -0.08 & & -0.06 & -0.03 & -0.03 \\
\hline
\end{tabular}

Note: Elasticity estimates are calculated only for significant variables. The top estimate uses a zero-growth steady-state scenario, and the bottom estimate is calculated using the average of the year-to-year growth rate of the explanatory variable. 


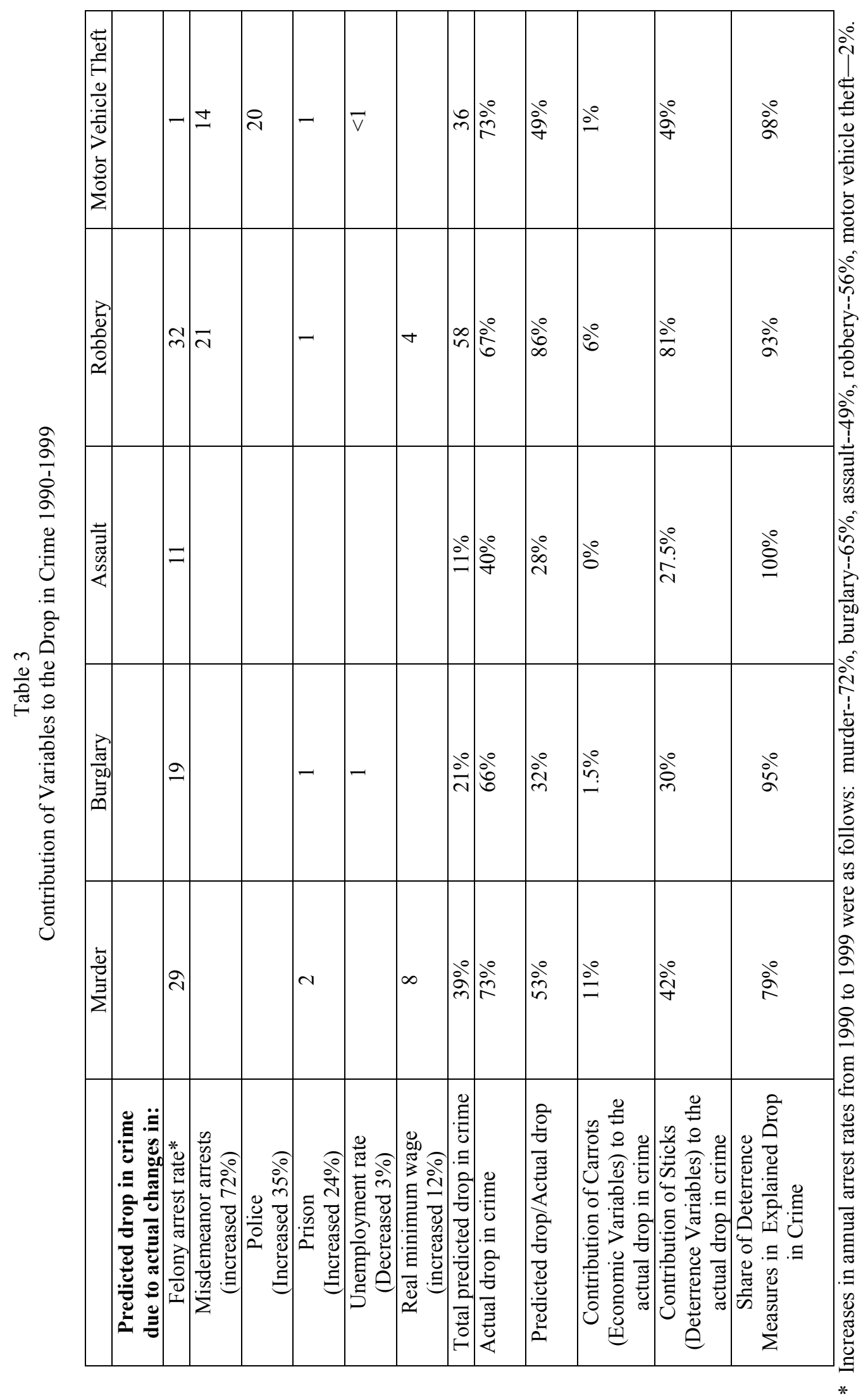




\section{$\underline{\text { References }}$}

Barclay, Gordon, Cynthia Tavares and Arsalaan Siddique, "International Comparisons of Criminal Justice Statistics 1999," Research Development \& Statistics Directorate, Home Office, U.K. 2001.

Blackburn, Keith and Morton O. Ravn, "Business Cycles in the United Kingdom: Facts and Fictions," Economica, 59, pp.383-401, 1992.

Cooper, Michael ," You're Under Burglary Arrest," The New York Times, 12/01/96, Vol. 146 Issue 50628, Section 13 p1, 0p, 1 chart, 1 graph, $10 \mathrm{bw}$.

Corman, Hope and H. Naci Mocan, "A Time-Series Analysis of Burglary, Deterrence, and Drug Abuse in New York City," American Economic Review, Vol. 90, No. 3, June 2000, pp. 584-604.

Corman, Hope, Theodore Joyce and Norman Lovitch, "Criminal Deterrence and the Business Cycle in New York City: A VAR Approach," Review of Economics and Statistics, Vol. 69, No. 4 (November 1987), pp. 695-700.

Donohue, John J. III, and Steven Levitt, "The Impact of Legalized Abortion on Burglary," Quarterly Journal of Economics, CXVI:II, pp. 379-420, May 2001.

Donohue, John J., III and Peter Siegelman, "Allocating Resources Among Prisons and Social Programs In the Battle Against Burglary," Journal of Legal Studies, Vol. 27, No. 1 pp. 1-44 January, 1998.

Freeman, Richard B. and William M. Rodgers III, "Area Economic Conditions and the Labor Market Outcomes of Young Men in the 1990s Expansion," in Prosperity for All? The Economic Boom and African Americans; Robert Cherry and William M. Rodgers (eds.), NY: Russell Sage Foundation, 2000.

Freeman, Richard B. ," The Economics of Burglary," Orley Ashenfelter and David Card, eds, Handbook of Labor Economics, Vol. 3C, Chapter 52, pp. 3529-71. Amsterdam: Netherlands, North-Holland Publishers, 1999.

Freeman, Richard B., "The Labor Market," Burglary, James Q. Wilson and Joan Petersilia (eds.), pp. 171-91. San Francisco: ICS Press, 1995.

Freeman, Richard B.; "Burglary and Unemployment." Burglary and Public Policy, Wilson, James Q. (ed.), San Francisco:ICS Press, p89-106, 1983.

Giacopassi, David and David R. Forde, " Broken Windows, Crumpled Fenders, and Burglary," Journal of Criminal Justice, Vol. 28, pp. 397-405, September/October 2000. 
Gould, Eric D., David B. Mustard and Bruce A. Weinberg, "Burglary Rates and Local Labor Market Opportunities in the United States: 1977-1997," The Review of Economics and Statistics, vol. 84, no. 1 (2002).

Grogger, Jeffrey T., "Market Wages and Youth Burglary," Journal of Labor Economics, Vol. 16, No. 4, October 1998, pp. 756-791.

Hashimoto, Masanori; "The Minimum Wage Law and Youth Burglarys: Time-Series Evidence." The Journal of Law and Economics, Vol 30, pp. 443-464, October 1987.

Hodrick, Robert J, and Edward C. Prescott, "Postwar U.S. Business Cycles: An Empirical Investigation," Journal of Money, Credit and Banking, 29(1), pp. 1-16, 1997.

Joyce Theodore and Naci Mocan, "The Impact of Legalized Abortion on Adoslescent Childbearing in New York City," American Journal of Public Health, 80:3, pp. 273-8, 1990.

Kahan, Dan M., "Social Meaning and the Economic Analysis of Burglary," The Journal of Legal Studies, XXVII(2) Part 2: 609-622, 1998.

Kelling, G. L. and J. Sousa, William H. (2001). Do Police Matter? An Analysis of the Impact of New York City's Police Reforms. New York, Center for Civic Innovation at the Manhattan Institute: 25.

Levitt, Steven D. ,"Why Do Increased Burglary Arrest Rates Appear to Reduce Burglary: Deterrence, Incapacitation, or Measurement Error?" Economic Inquiry, Vol. 36, No. 3, pp. 353-372, July 1998a.

Levitt, Steven D.; "Juvenile Burglary and Punishment." Journal of Political Economy, Vol 106, No 6, p1156-1185, December 1998b

Levitt, Steven D.; "Using Electoral Cycles in Police Hiring to Estimate the Effect of Police on Burglary." The American Economic Review, Vol 87, No 3, p270-290, June 1997.

Levitt, Steven D.; "The Effect of Prison Population Size on Burglary Rates: Evidence from Prison Overcrowding Litigation." The Quarterly Journal of Economics, Vol 3, No 2, p319-351, May 1996

Marvell, Thomas B. and Carlisle E. Moody, "Prison Population Growth and Burglary Reduction," Journal of Quantitative Criminology, Vol. 10 pp. 109-40 March 1994.

Mocan, H. Naci, "Structural Unemployment, Cyclical Unemployment, and Income Inequality," Review of Economics and Statistics, Vol. 81, No. 1, pp122-135, 
February, 1999.

Mocan, H. Naci, and R. Kaj Gittings, " Removals from Death Row, Executions and Homicide," May 2002. Working Paper, University of Colorado at Denver. Revised version of NBER Working Paper No: 8639.

Mustard, David B., "Reexamining Criminal Behavior: The Importance of Omitted Variable Bias," The Review of Economics and Statistics, forthcoming.

Nelson, James F., " Racial and Ethnic Disparities in Processing Persons Burglary Arrested for Misdemeanor Burglarys: New York State, 1985-1986," Office of Justice Systems Analysis, New York State Division of Criminal Justice Services, July, 1991.

Nelson, James F., " Disparities in Processing Felony Burglary Arrests in New York State, 1990-1992," Bureau of Research and Evaluation, New York State Division of Criminal Justice Services, July, 1995.

Nichols, Hans, "Criminal Thoughts: Giuliani's Shadow," The Wall Street Journal Europe, April 19, 2002, p. A12.

Pfeiffer, Christian, "Trends in Juvenile Violence in European Countries," National Institute of Justice Research Preview, May 1998.

Raphael, Steven and Rudolf Winter-Ebmer , "Identifying the Effect of Unemployment on Burglary," Journal of Law and Economics, 44(1): 259-284 , 2001.

Sampson, R. J. and J. Cohen, "Deterrent Effects of the Police on Burglary: A Replication and Theoretical Extension," Law \& Society Review. 1988

Vinocur, John, "Candidates Skirt Facts on Burglary in France," International Herald Tribune, April 3, 2002.

Wilson, J. Q. and G. L. Kelling (1982). Broken Windows. Atlantic Monthly. 249: 29-38. 


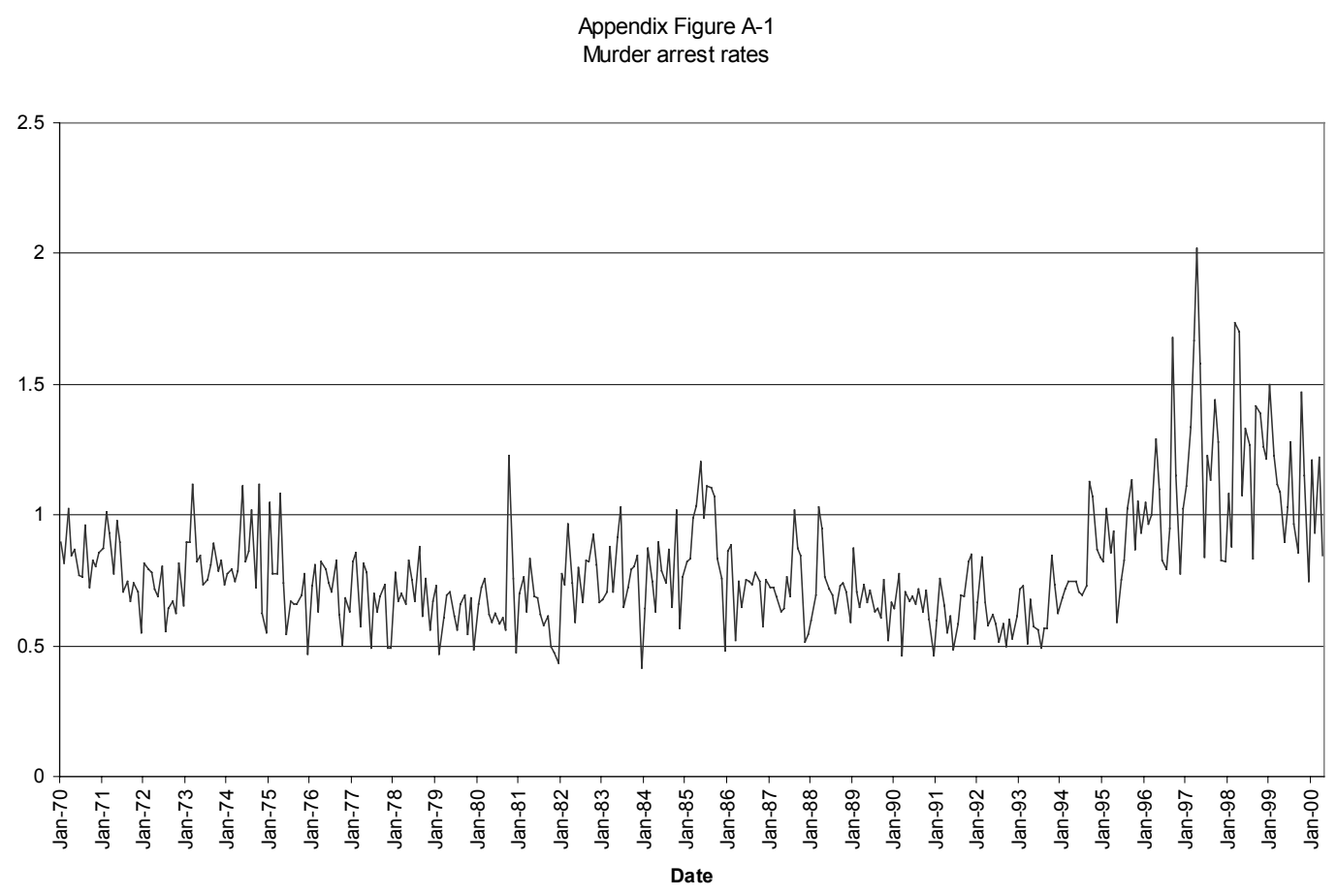

Appendix Figure A-2

Burglary Arrest Rates

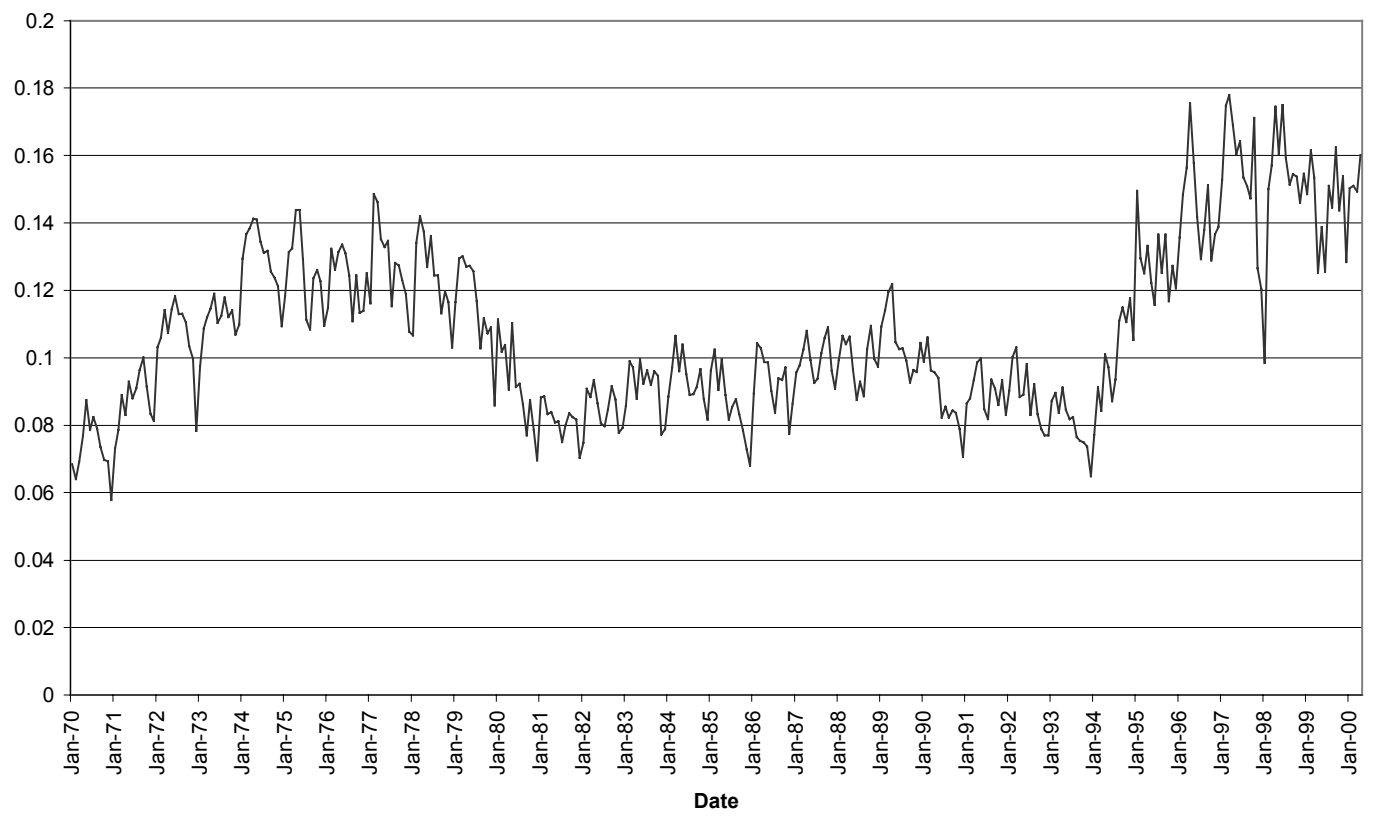


Appendix Figure A-3

Assault Arrest Rates

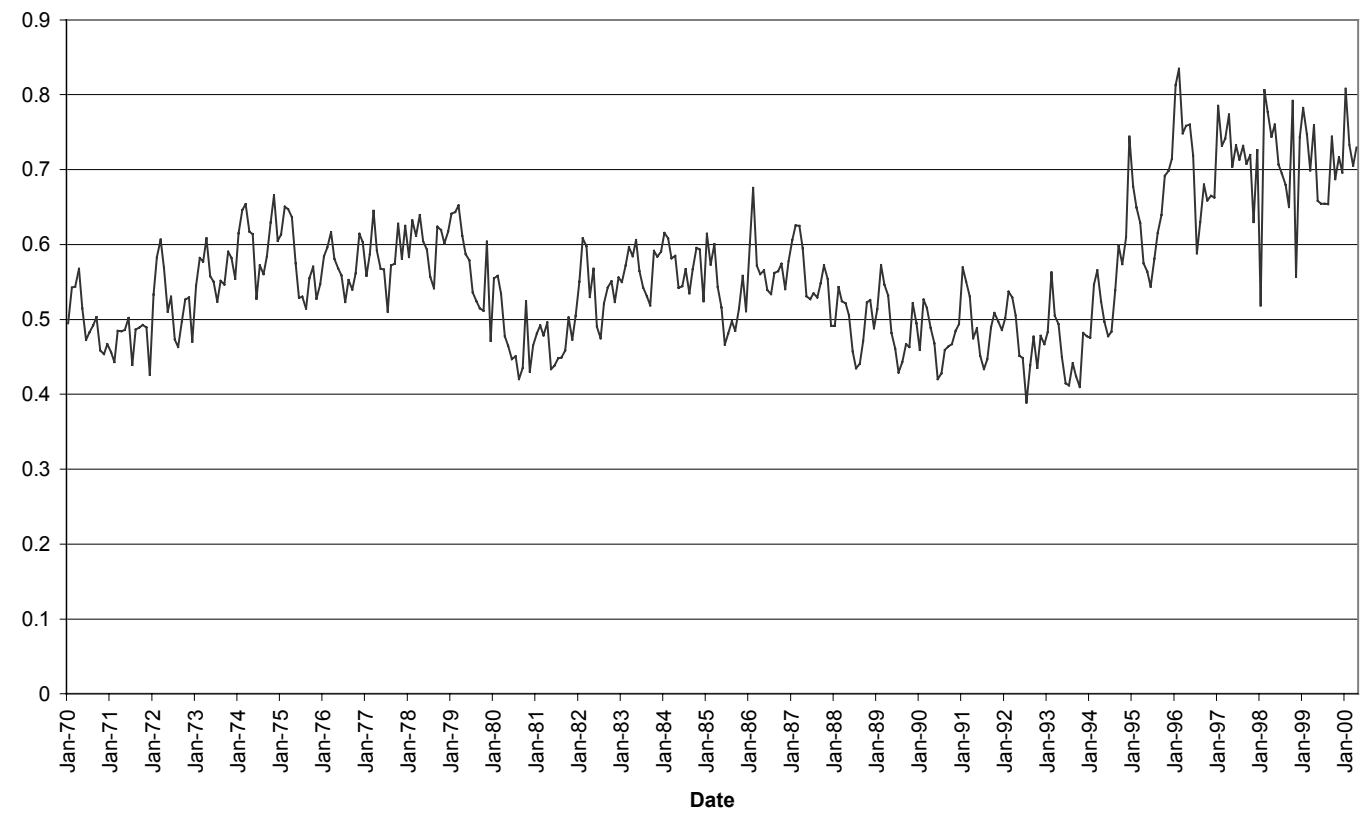

Appendix Figure A-4

Robbery Arrest Rate

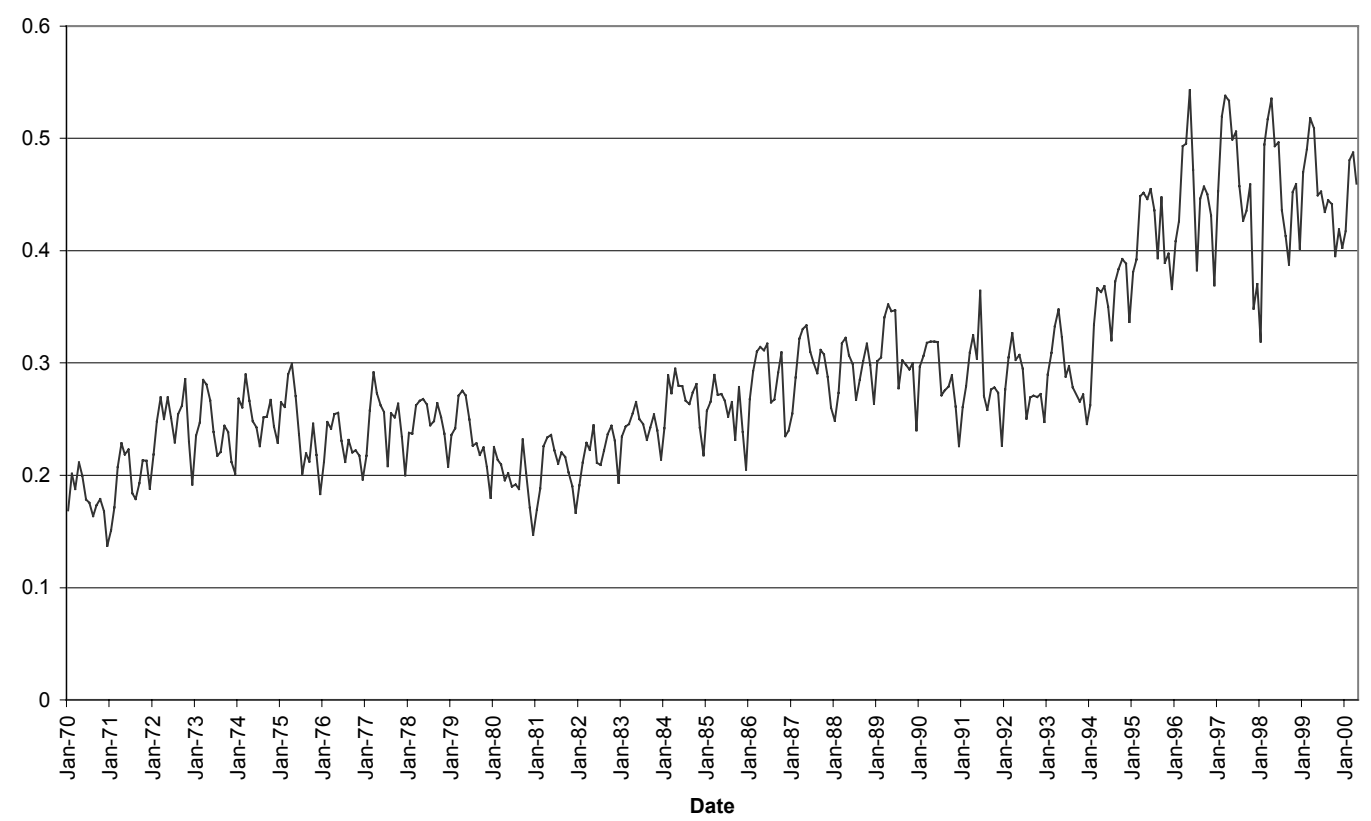


Appendix Figure A-5

Motor Vehicle Theft Arrest Rates

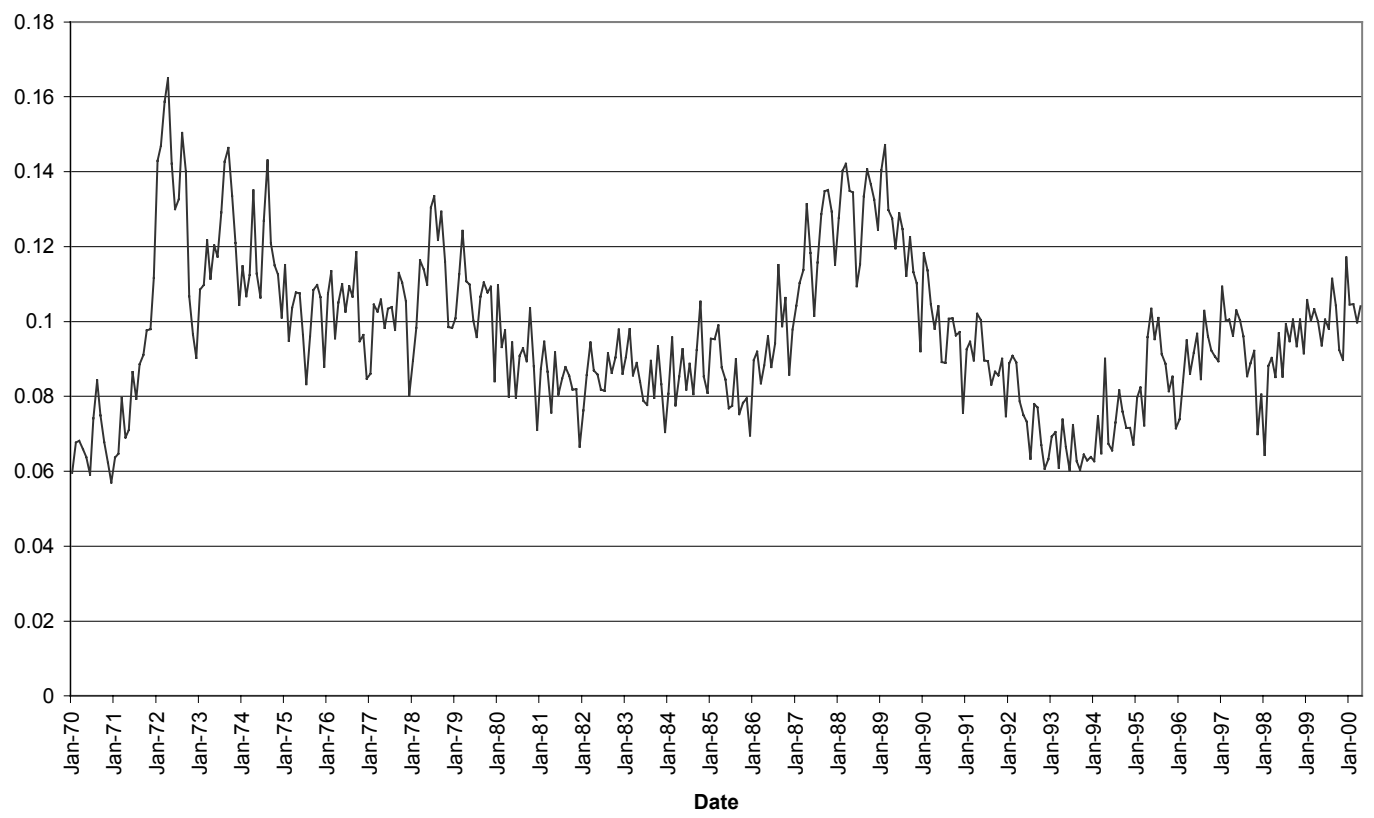

Appendix Figure A-6

Non-Drug Misdemeanor Arrests

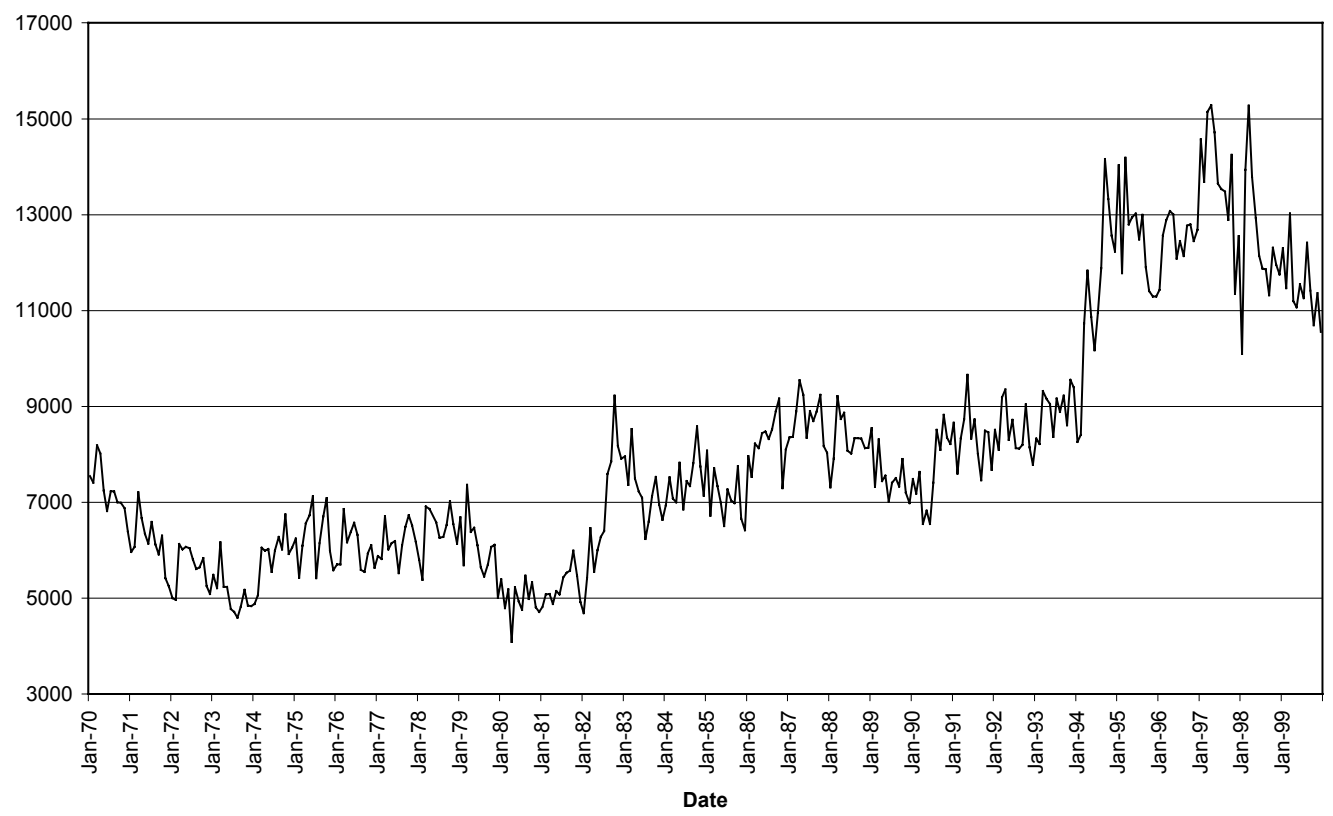


Appendix Table A-1

Tests for Unit Root and Co-Integration

\begin{tabular}{|l|l|l|}
\hline Variable & Unit Root Tests & Co-integration Tests \\
\hline Murder & -0.83 & -11.36 \\
\hline Assault & -0.63 & -6.76 \\
\hline Burglary & -0.24 & -4.85 \\
\hline Robbery & 0.09 & -5.81 \\
\hline Motor Vehicle Theft & 0.08 & -4.32 \\
\hline Murder Arrest & -1.44 & \\
\hline Assault Arrest & -2.42 & \\
\hline Burglary Arrest & -2.59 & \\
\hline Robbery Arrest & -0.15 & \\
\hline Motor Vehicle Arrest & -1.16 & \\
\hline Prison Population & $-4.75^{*}$ & \\
\hline Youth Population & $-3.64 *$ & \\
\hline Unemployment rate & -2.21 & \\
\hline Real Minimum Wage & -1.87 & \\
\hline Misdemeanor Arrests & -2.85 & \\
\hline Police & -1.47 & \\
\hline & & \\
\hline & & \\
\hline & & \\
\hline & & \\
\hline
\end{tabular}

Unit root tests are based on the regression $\Delta \mathrm{X}_{\mathrm{t}}=\mu+\alpha \mathrm{t}+\beta \mathrm{X}_{\mathrm{t}-\mathrm{i}}+\Sigma \Omega_{\mathrm{i}} \Delta \mathrm{X}_{\mathrm{t}-\mathrm{i}}+\epsilon_{\mathrm{t} .}$ An asterisk indicates that the hypothesis of a unit root is rejected. The co-integration test involves running $\Delta \mathrm{Y}_{\mathrm{t}}=\mu+\beta \mathrm{Y}_{\mathrm{t}-1}+\epsilon_{\mathrm{t}}$, where $\mathrm{Y}$ stands for the residuals of the cointegrating regression. All variables are de-seasonalized. 
Appendix Table A-2

Full Results

The Determinants of Murder

\begin{tabular}{|c|c|c|}
\hline Variable & Coefficient & Std Error \\
\hline Murder $\{1\}$ & $-0.53874 * * *$ & $(0.095)$ \\
\hline Murder $\{2\}$ & $-0.4612 * * *$ & $(0.111)$ \\
\hline Murder $\{3\}$ & $-0.3639 * * *$ & $(0.093)$ \\
\hline Murder $\{4\}$ & $-0.3022 * * *$ & $(0.079)$ \\
\hline Murder $\{5\}$ & $-0.2532 * * *$ & $(0.092)$ \\
\hline Murder $\{6\}$ & $-0.1884 * *$ & $(0.077)$ \\
\hline Murder $\{7\}$ & -0.0529 & $(0.054)$ \\
\hline Murder Arrests $\{1\}$ & $-0.212 * * *$ & $(0.068)$ \\
\hline Murder Arrests $\{2\}$ & $-0.1692 * *$ & $(0.081)$ \\
\hline Murder Arrests $\{3\}$ & $-0.1382 * *$ & $(0.069)$ \\
\hline Murder Arrests $\{4\}$ & -0.059 & $(0.073)$ \\
\hline Murder Arrests $\{5\}$ & -0.0902 & $(0.067)$ \\
\hline Police & 0.1182 & $(0.543)$ \\
\hline Police $\{1\}$ & -0.1185 & $(0.423)$ \\
\hline Police $\{2\}$ & -0.4708 & $(0.463)$ \\
\hline Misdemeanor Arrests $\{1\}$ & -0.1051 & $(0.080)$ \\
\hline Misdemeanor Arrests $\{2\}$ & -0.1754 & $(0.136)$ \\
\hline Misdemeanor Arrests $\{3\}$ & -0.0489 & $(0.125)$ \\
\hline Misdemeanor Arrests $\{4\}$ & -0.1336 & $(0.094)$ \\
\hline Misdemeanor Arrests $\{5\}$ & $-0.1624 *$ & $(0.096)$ \\
\hline NYC Unemployment rate & 0.3245 & $(0.215)$ \\
\hline NYC Unemployment rate $\{1\}$ & 0.2032 & $(0.124)$ \\
\hline NYC Unemployment rate $\{2\}$ & $-0.2542 * * *$ & $(0.097)$ \\
\hline NYC Minimum wage & $-0.6936 * * *$ & $(0.229)$ \\
\hline Prison population $\{1\}$ & -0.457 & $(1.638)$ \\
\hline Prison population $\{2\}$ & $5.8711 * *$ & $(2.945)$ \\
\hline Prison population $\{3\}$ & $-7.6085 * * *$ & $(2.395)$ \\
\hline Prison population $\{4\}$ & 1.8282 & $(2.136)$ \\
\hline Prison population $\{5\}$ & -2.4489 & $(2.469)$ \\
\hline Prison population $\{6\}$ & 1.1419 & $(3.012)$ \\
\hline Prison population $\{7\}$ & 3.7759 & $(3.658)$ \\
\hline Prison population $\{8\}$ & -2.1791 & $(1.926)$ \\
\hline Teen population & 6.4249 & $(9.139)$ \\
\hline Teen population $\{1\}$ & -16.7925 & $(28.816)$ \\
\hline Teen population $\{2\}$ & 13.5529 & $(27.259)$ \\
\hline Teen population $\{4\}$ & -10.8512 & $(24.404)$ \\
\hline Teen population $\{6\}$ & 24.1899 & $(33.151)$ \\
\hline Teen population $\{8\}$ & -32.392 & $(30.551)$ \\
\hline Teen population $\{10\}$ & 21.7136 & $(15.872)$ \\
\hline
\end{tabular}


(Table A-2 concluded)

\begin{tabular}{lcc}
\hline Teen population $\{12\}$ & $-5.8549^{*}$ & $(3.507)$ \\
January & $-0.2881^{* * *}$ & $(0.051)$ \\
February & $-0.3922^{* * *}$ & $(0.055)$ \\
March & $-0.1736^{* * *}$ & $(0.061)$ \\
April & $-0.2469^{* * *}$ & $(0.051)$ \\
May & $-0.1767 * * *$ & $(0.063)$ \\
June & $-0.1172^{* *}$ & $(0.050)$ \\
July & $-0.1121^{* *}$ & $(0.055)$ \\
August & $-0.1281^{* *}$ & $(0.051)$ \\
September & -0.0863 & $(0.055)$ \\
October & $-0.2049 * * *$ & $(0.046)$ \\
November & $-0.1381 * * *$ & $(0.040)$ \\
Error correction term $\{1\}$ & $-0.2866^{* * *}$ & $(0.085)$ \\
Constant & $12.9855^{* * *}$ & $(3.933)$ \\
\hline
\end{tabular}

Note: $*, * *$, or $* * *$ signify statistical significance at the $10 \%, 5 \%$, and $1 \%$ levels, respectively. 
Appendix Table A-3

Full Results

The Determinants of Burglary

\begin{tabular}{|c|c|c|}
\hline Variable & Coefficient & Std Error \\
\hline Burglary $\{1\}$ & $-0.3536 * * *$ & $(0.058)$ \\
\hline Burglary $\{2\}$ & $-0.188 * * *$ & $(0.060)$ \\
\hline Burglary $\{3\}$ & -0.0292 & $(0.072)$ \\
\hline Burglary $\{4\}$ & $-0.1392 * *$ & $(0.066)$ \\
\hline Burglary $\{5\}$ & -0.0068 & $(0.053)$ \\
\hline Burglary $\{6\}$ & -0.0117 & $(0.073)$ \\
\hline Burglary $\{7\}$ & $-0.1446 *$ & $(0.085)$ \\
\hline Burglary $\{8\}$ & -0.0835 & $(0.078)$ \\
\hline Burglary $\{9\}$ & 0.0163 & $(0.052)$ \\
\hline Burglary Arrests $\{1\}$ & $-0.0742 * *$ & $(0.036)$ \\
\hline Burglary Arrests $\{2\}$ & $-0.0712 *$ & $(0.039)$ \\
\hline Burglary Arrests $\{3\}$ & $-0.0592 *$ & $(0.035)$ \\
\hline Burglary Arrests $\{4\}$ & -0.0041 & $(0.040)$ \\
\hline Burglary Arrests $\{5\}$ & $-0.0695 * *$ & $(0.033)$ \\
\hline Burglary Arrests $\{6\}$ & $-0.1267 * * *$ & $(0.048)$ \\
\hline Burglary Arrests $\{7\}$ & $-0.0508 *$ & $(0.029)$ \\
\hline Burglary Arrests $\{8\}$ & $-0.0927 * *$ & $(0.038)$ \\
\hline Burglary Arrests $\{9\}$ & -0.0055 & $(0.040)$ \\
\hline Burglary Arrests $\{10\}$ & -0.0347 & $(0.034)$ \\
\hline Burglary Arrests $\{11\}$ & 0.0002 & $(0.037)$ \\
\hline Burglary Arrests $\{12\}$ & 0.038 & $(0.037)$ \\
\hline Burglary Arrests $\{13\}$ & $0.0963 * *$ & $(0.048)$ \\
\hline Burglary Arrests $\{14\}$ & 0.054 & $(0.038)$ \\
\hline Burglary Arrests $\{15\}$ & 0.0235 & $(0.033)$ \\
\hline Burglary Arrests $\{16\}$ & 0.0024 & $(0.037)$ \\
\hline Burglary Arrests $\{17\}$ & 0.0421 & $(0.038)$ \\
\hline Burglary Arrests $\{18\}$ & 0.0374 & $(0.045)$ \\
\hline Burglary Arrests $\{19\}$ & $-0.0834 * * *$ & $(0.030)$ \\
\hline Burglary Arrests $\{20\}$ & -0.0607 & $(0.038)$ \\
\hline Burglary Arrests $\{21\}$ & -0.0332 & $(0.029)$ \\
\hline Police & -0.1785 & $(0.253)$ \\
\hline Police $\{1\}$ & -0.102 & $(0.191)$ \\
\hline Misdemeanor Arrests $\{1\}$ & -0.0325 & $(0.040)$ \\
\hline Misdemeanor Arrests $\{2\}$ & -0.021 & $(0.034)$ \\
\hline NYC Unemployment rate & 0.0317 & $(0.047)$ \\
\hline NYC Unemployment rate $\{1\}$ & $0.1024 * *$ & $(0.046)$ \\
\hline NYC Unemployment rate $\{2\}$ & 0.0279 & $(0.049)$ \\
\hline NYC Minimum wage & 0.025 & $(0.113)$ \\
\hline NYC Minimum wage $\{1\}$ & -0.0741 & $(0.208)$ \\
\hline NYC Minimum wage $\{2\}$ & $0.3765 * * *$ & $(0.134)$ \\
\hline Prison population $\{1\}$ & $-1.3678 * * *$ & $(0.451)$ \\
\hline
\end{tabular}


(Table A-3 concluded)

\begin{tabular}{|c|c|c|}
\hline Prison population $\{2\}$ & 0.4452 & $(0.868)$ \\
\hline Prison population $\{3\}$ & 0.1779 & $(1.085)$ \\
\hline Prison population $\{4\}$ & $1.7763 *$ & $(1.042)$ \\
\hline Prison population $\{5\}$ & $-1.8081 * *$ & $(0.869)$ \\
\hline Prison population $\{6\}$ & 0.4044 & $(0.967)$ \\
\hline Prison population $\{7\}$ & 0.526 & $(0.967)$ \\
\hline Prison population $\{8\}$ & -1.157 & $(0.917)$ \\
\hline Prison population $\{9\}$ & 0.478 & $(0.926)$ \\
\hline Prison population $\{10\}$ & 1.1226 & $(1.137)$ \\
\hline Prison population $\{11\}$ & -1.1907 & $(0.917)$ \\
\hline Prison population $\{12\}$ & -0.4413 & $(1.082)$ \\
\hline Prison population $\{13\}$ & 1.0001 & $(1.019)$ \\
\hline Prison population $\{14\}$ & -0.9498 & $(0.992)$ \\
\hline Prison population $\{15\}$ & 0.8878 & $(0.902)$ \\
\hline Prison population $\{16\}$ & 1.329 & $(1.085)$ \\
\hline Prison population $\{17\}$ & $-3.2148 * * *$ & $(1.000)$ \\
\hline Prison population $\{18\}$ & $1.9243 * *$ & $(0.785)$ \\
\hline Teen population & $208.5542 * * *$ & $(0.000)$ \\
\hline Teen population $\{1\}$ & $-686.5794 * * *$ & $(0.000)$ \\
\hline Teen population $\{2\}$ & $690.5012 * * *$ & $(0.000)$ \\
\hline Teen population $\{4\}$ & $-327.04 * * *$ & $(0.000)$ \\
\hline Teen population $\{6\}$ & $157.8234 * * *$ & $(0.000)$ \\
\hline Teen population $\{8\}$ & -50.8854 & $(73.524)$ \\
\hline Teen population $\{10\}$ & 8.79 & (47.769) \\
\hline Teen population $\{12\}$ & -1.2094 & $(11.502)$ \\
\hline January & $-0.0392 * *$ & $(0.018)$ \\
\hline February & $-0.1214 * * *$ & $(0.024)$ \\
\hline March & $0.034^{*}$ & $(0.020)$ \\
\hline April & $-0.0442 * *$ & $(0.022)$ \\
\hline May & 0.0252 & $(0.020)$ \\
\hline June & -0.0288 & $(0.024)$ \\
\hline July & $0.0615 * * *$ & $(0.022)$ \\
\hline August & 0.0394 & $(0.031)$ \\
\hline September & -0.0238 & $(0.023)$ \\
\hline October & 0.0172 & $(0.016)$ \\
\hline November & $-0.0387 * *$ & $(0.020)$ \\
\hline Error correction term $\{1\}$ & $-0.0973 * * *$ & $(0.030)$ \\
\hline Constant & $6.5654 * * *$ & $(0.959)$ \\
\hline
\end{tabular}

Note: $*, * *$, or $* * *$ signify statistical significance at the $10 \%, 5 \%$, and $1 \%$ levels, respectively. 
Appendix Table A-4

Full Results

The Determinants of Assault

\begin{tabular}{|c|c|c|}
\hline Variable & Coefficient & Std Error \\
\hline Assault $\{1\}$ & $-0.4744 * * *$ & $(0.087)$ \\
\hline Assault $\{2\}$ & $-0.26^{* * *}$ & $(0.097)$ \\
\hline Assault $\{3\}$ & $-0.1815^{*}$ & $(0.100)$ \\
\hline Assault $\{4\}$ & $-0.1676^{*}$ & $(0.095)$ \\
\hline Assault $\{5\}$ & $-0.2524 * * *$ & $(0.088)$ \\
\hline Assault $\{6\}$ & $-0.1338^{*}$ & $(0.080)$ \\
\hline Assault $\{7\}$ & -0.1094 & $(0.067)$ \\
\hline Assault $\{8\}$ & -0.0533 & $(0.076)$ \\
\hline Assault $\{9\}$ & 0.0482 & $(0.059)$ \\
\hline Assault Arrests $\{1\}$ & -0.0678 & $(0.058)$ \\
\hline Assault Arrests $\{2\}$ & -0.0681 & $(0.062)$ \\
\hline Assault Arrests $\{3\}$ & $-0.1001 *$ & $(0.056)$ \\
\hline Assault Arrests $\{4\}$ & -0.0123 & $(0.050)$ \\
\hline Police & -0.1728 & $(0.200)$ \\
\hline Police $\{1\}$ & 0.1419 & $(0.179)$ \\
\hline Misdemeanor Arrests $\{1\}$ & 0.0467 & $(0.043)$ \\
\hline Misdemeanor Arrests $\{2\}$ & 0.0287 & $(0.051)$ \\
\hline NYC Unemployment rate & $0.1363^{*}$ & $(0.081)$ \\
\hline NYC Unemployment rate $\{1\}$ & -0.0581 & $(0.074)$ \\
\hline NYC Minimum wage & -0.0359 & $(0.143)$ \\
\hline NYC Minimum wage $\{1\}$ & 0.2168 & $(0.154)$ \\
\hline Prison population $\{1\}$ & 0.2181 & $(0.633)$ \\
\hline Prison population $\{2\}$ & -1.1809 & (1.175) \\
\hline Prison population $\{3\}$ & 1.7936 & (1.638) \\
\hline Prison population $\{4\}$ & 0.0683 & (1.753) \\
\hline Prison population $\{5\}$ & -0.9064 & $(0.808)$ \\
\hline Teen population & 468.367 & $(883.768)$ \\
\hline Teen population $\{1\}$ & -2606.8104 & $(2940.081)$ \\
\hline Teen population $\{2\}$ & 3919.5578 & (3009.194) \\
\hline Teen population $\{4\}$ & $-3534.6163^{* *}$ & $(1698.657)$ \\
\hline Teen population $\{6\}$ & $3035.0497 * *$ & $(1410.602)$ \\
\hline Teen population $\{8\}$ & -1900.7907 & $(1161.810)$ \\
\hline Teen population $\{10\}$ & 762.6579 & $(634.172)$ \\
\hline Teen population $\{12\}$ & -143.6337 & $(154.697)$ \\
\hline January & 0.0344 & $(0.025)$ \\
\hline February & -0.0416 & $(0.028)$ \\
\hline March & $0.2018^{* * *}$ & $(0.035)$ \\
\hline April & $0.1692 * * *$ & $(0.037)$ \\
\hline May & $0.2615^{* * *}$ & $(0.043)$ \\
\hline June & $0.2896^{* * *}$ & $(0.047)$ \\
\hline July & $0.2592 * * *$ & $(0.048)$ \\
\hline
\end{tabular}


(Table A-4 concluded)

\begin{tabular}{lcc}
\hline August & $0.2443^{* * *}$ & $(0.051)$ \\
September & $0.075^{*}$ & $(0.045)$ \\
October & $0.0955^{* *}$ & $(0.045)$ \\
November & 0.0478 & $(0.031)$ \\
Error correction term $\{1\}$ & $-0.1214^{*}$ & $(0.069)$ \\
Constant & $2.7949^{*}$ & $(1.532)$ \\
\hline
\end{tabular}

Note: ${ }^{*}, * *$, or ${ }^{* * *}$ signify statistical significance at the $10 \%, 5 \%$, and $1 \%$ levels, respectively. 
Appendix Table A-5

Full Results

The Determinants of Robbery

\begin{tabular}{|c|c|c|}
\hline Variable & Coefficient & Std Error \\
\hline Robbery $\{1\}$ & $-0.2958 * * *$ & $(0.082)$ \\
\hline Robbery $\{2\}$ & -0.1127 & $(0.087)$ \\
\hline Robbery $\{3\}$ & -0.0103 & $(0.077)$ \\
\hline Robbery $\{4\}$ & 0.026 & $(0.042)$ \\
\hline Robbery $\{5\}$ & -0.032 & $(0.036)$ \\
\hline Robbery Arrests $\{1\}$ & $-0.1077 * *$ & $(0.048)$ \\
\hline Robbery Arrests $\{2\}$ & -0.1022 & $(0.073)$ \\
\hline Robbery Arrests $\{3\}$ & $-0.1363 * *$ & $(0.059)$ \\
\hline Robbery Arrests $\{4\}$ & $-0.1255 * * *$ & $(0.041)$ \\
\hline Robbery Arrests $\{5\}$ & $-0.1514 * * *$ & $(0.045)$ \\
\hline Robbery Arrests $\{6\}$ & $-0.1909 * * *$ & $(0.041)$ \\
\hline Robbery Arrests $\{7\}$ & $-0.0664^{*}$ & $(0.035)$ \\
\hline Robbery Arrests $\{8\}$ & -0.0507 & $(0.040)$ \\
\hline Robbery Arrests $\{9\}$ & $-0.0832 * *$ & $(0.042)$ \\
\hline Robbery Arrests $\{10\}$ & $-0.1224 * * *$ & $(0.039)$ \\
\hline Robbery Arrests $\{11\}$ & $-0.1458 * * *$ & $(0.039)$ \\
\hline Robbery Arrests $\{12\}$ & -0.0398 & $(0.030)$ \\
\hline Police & -0.0113 & $(0.218)$ \\
\hline Police $\{1\}$ & -0.1172 & $(0.194)$ \\
\hline Police $\{2\}$ & -0.2615 & $(0.224)$ \\
\hline Misdemeanor Arrests $\{1\}$ & $-0.1293 * * *$ & $(0.033)$ \\
\hline Misdemeanor Arrests $\{2\}$ & $-0.1178 * * *$ & $(0.031)$ \\
\hline NYC Unemployment rate & -0.0564 & $(0.046)$ \\
\hline NYC Unemployment rate $\{1\}$ & $-0.0858 * * *$ & $(0.032)$ \\
\hline NYC Unemployment rate $\{2\}$ & -0.0083 & $(0.056)$ \\
\hline NYC Minimum wage & $-0.2707 * *$ & $(0.137)$ \\
\hline NYC Minimum wage $\{1\}$ & -0.1033 & $(0.130)$ \\
\hline Prison population $\{1\}$ & -0.7517 & $(0.517)$ \\
\hline Prison population $\{2\}$ & -0.4815 & $(0.777)$ \\
\hline Prison population $\{3\}$ & 1.4209 & $(1.126)$ \\
\hline Prison population $\{4\}$ & 0.809 & $(1.535)$ \\
\hline Prison population $\{5\}$ & -1.7438 & $(1.204)$ \\
\hline Prison population $\{6\}$ & 0.5876 & $(0.642)$ \\
\hline Prison population $\{7\}$ & -0.0029 & $(0.652)$ \\
\hline Prison population $\{8\}$ & -0.6471 & $(0.744)$ \\
\hline Prison population $\{9\}$ & 0.4798 & $(1.108)$ \\
\hline Prison population $\{10\}$ & 0.0146 & $(1.437)$ \\
\hline Prison population $\{11\}$ & 0.2862 & $(0.761)$ \\
\hline Teen population & $2817.0828^{* * *}$ & $(841.814)$ \\
\hline Teen population $\{1\}$ & $-9632.7263 * * *$ & $(3201.098)$ \\
\hline Teen population $\{2\}$ & $9956.7429 * * *$ & $(3787.168)$ \\
\hline
\end{tabular}


(Table A-5 concluded)

\begin{tabular}{lcc}
\hline Teen population $\{4\}$ & $-4719.9389^{*}$ & $(2632.832)$ \\
Teen population $\{6\}$ & 2090.1509 & $(1962.186)$ \\
Teen population $\{8\}$ & -584.9609 & $(1139.855)$ \\
Teen population $\{10\}$ & 70.114 & $(448.770)$ \\
Teen population $\{12\}$ & 3.2492 & $(88.722)$ \\
January & $-0.081^{* * *}$ & $(0.0210)$ \\
February & $-0.1731^{* * *}$ & $(0.020)$ \\
March & $-0.0465^{* * *}$ & $(0.018)$ \\
April & $-0.1107^{* * *}$ & $(0.023)$ \\
May & -0.0172 & $(0.028)$ \\
June & -0.0065 & $(0.020)$ \\
July & 0.015 & $(0.019)$ \\
August & 0.0175 & $(0.015)$ \\
September & $-0.0463^{* * *}$ & $(0.017)$ \\
October & -0.0148 & $(0.018)$ \\
November & $-0.0754 * * *$ & $(0.013)$ \\
Error correction term $\{1\}$ & $-0.0879 * *$ & $(0.035)$ \\
Constant & $4.1022^{* * *}$ & $(0.924)$ \\
\hline
\end{tabular}

Note: $*, * *$, or $* * *$ signify statistical significance at the $10 \%, 5 \%$, and $1 \%$ levels, respectively. 
Appendix Table A-6

Full Results

The Determinants of Motor Vehicle Theft

\begin{tabular}{|c|c|c|}
\hline Variable & Coefficient & Std Error \\
\hline Motor Vehicle Theft $\{1\}$ & $-0.4097 * * *$ & $(0.076)$ \\
\hline Motor Vehicle Theft $\{2\}$ & $-0.0755 * *$ & $(0.038)$ \\
\hline Motor Vehicle Theft Arrests $\{1\}$ & -0.0588 & $(0.042)$ \\
\hline Motor Vehicle Theft Arrests $\{2\}$ & $-0.1759 * * *$ & $(0.049)$ \\
\hline Motor Vehicle Theft Arrests $\{3\}$ & $-0.1339 * * *$ & $(0.033)$ \\
\hline Motor Vehicle Theft Arrests $\{4\}$ & $-0.0972 * * *$ & $(0.037)$ \\
\hline Motor Vehicle Theft Arrests $\{5\}$ & $-0.1183 * * *$ & $(0.031)$ \\
\hline Motor Vehicle Theft Arrests $\{6\}$ & $-0.1214^{* * *}$ & $(0.039)$ \\
\hline Motor Vehicle Theft Arrests $\{7\}$ & $-0.0842 * *$ & $(0.034)$ \\
\hline Motor Vehicle Theft Arrests $\{8\}$ & $-0.0824 * *$ & $(0.034)$ \\
\hline Motor Vehicle Theft Arrests $\{9\}$ & -0.0309 & $(0.037)$ \\
\hline Motor Vehicle Theft Arrests $\{10\}$ & -0.0228 & $(0.036)$ \\
\hline Motor Vehicle Theft Arrests $\{11\}$ & -0.0414 & $(0.037)$ \\
\hline Motor Vehicle Theft Arrests $\{12\}$ & $-0.0802 *$ & $(0.043)$ \\
\hline Motor Vehicle Theft Arrests $\{13\}$ & 0.0061 & $(0.033)$ \\
\hline Motor Vehicle Theft Arrests $\{14\}$ & -0.002 & $(0.028)$ \\
\hline Police & 0.0726 & $(0.215)$ \\
\hline Police $\{1\}$ & $-0.4457 * *$ & $(0.196)$ \\
\hline Police $\{2\}$ & -0.2038 & $(0.146)$ \\
\hline Misdemeanor Arrests $\{1\}$ & $-0.135 * * *$ & $(0.039)$ \\
\hline Misdemeanor Arrests $\{2\}$ & -0.0218 & $(0.043)$ \\
\hline NYC Unemployment rate & $0.1239 * * *$ & $(0.045)$ \\
\hline NYC Minimum wage & -0.2712 & $(0.189)$ \\
\hline NYC Minimum wage $\{1\}$ & -0.2605 & $(0.202)$ \\
\hline NYC Minimum wage $\{2\}$ & $0.2651 * * *$ & $(0.084)$ \\
\hline Prison population $\{1\}$ & -0.3992 & $(0.421)$ \\
\hline Prison population $\{2\}$ & 0.7225 & $(0.73)$ \\
\hline Prison population $\{3\}$ & -1.1617 & $(0.918)$ \\
\hline Prison population $\{4\}$ & 1.0593 & $(0.915)$ \\
\hline Prison population $\{5\}$ & -0.1946 & $(1.128)$ \\
\hline Prison population $\{6\}$ & 0.1103 & $(1.293)$ \\
\hline Prison population $\{7\}$ & 0.2825 & $(0.975)$ \\
\hline Prison population $\{8\}$ & -0.4467 & $(0.609)$ \\
\hline Teen population & $19.0877 * * *$ & $(6.587)$ \\
\hline Teen population $\{1\}$ & $-56.7799 * * *$ & $(20.443)$ \\
\hline Teen population $\{2\}$ & $48.1148 * *$ & $(19.214)$ \\
\hline Teen population $\{4\}$ & -6.5747 & $(9.507)$ \\
\hline Teen population $\{6\}$ & $-15.7994 * *$ & $(8.013)$ \\
\hline Teen population $\{8\}$ & $21.7212 * * *$ & $(6.468)$ \\
\hline Teen population $\{10\}$ & $-12.5658 * * *$ & $(3.422)$ \\
\hline Teen population $\{12\}$ & $2.7924 * * *$ & $(0.819)$ \\
\hline
\end{tabular}


(Table A-6 concluded)

\begin{tabular}{lcc}
\hline January & -0.0054 & $(0.015)$ \\
February & $-0.0905^{* * *}$ & $(0.023)$ \\
March & $0.0843^{* * *}$ & $(0.018)$ \\
April & $0.0359^{*}$ & $(0.020)$ \\
May & $0.0645^{* * *}$ & $(0.023)$ \\
June & $0.0374^{* *}$ & $(0.018)$ \\
July & $0.0891 * * *$ & $(0.025)$ \\
August & $0.1142^{* * *}$ & $(0.025)$ \\
September & $0.0594 * * *$ & $(0.018)$ \\
October & $0.0906^{* * *}$ & $(0.021)$ \\
November & 0.0074 & $(0.015)$ \\
Error correction term $\{1\}$ & $-0.1469 * * *$ & $(0.031)$ \\
Constant & $5.0534 * * *$ & $(1.118)$ \\
\hline
\end{tabular}

Note: $*, * *$, or $* * *$ signify statistical significance at the $10 \%, 5 \%$, and $1 \%$ levels, respectively. 
Appendix Table A-7

Arbitrary Lag Lengths

\begin{tabular}{|c|c|c|c|c|}
\hline $\begin{array}{l}\text { Number of } \\
\text { Lags }\end{array}$ & $\begin{array}{c}\text { Own } \\
\text { Arrests }\end{array}$ & $\begin{array}{c}\text { Total Misd. } \\
\text { Arrests }\end{array}$ & $\begin{array}{c}\text { Unemployment } \\
\text { Rate }\end{array}$ & $\begin{array}{c}\text { NYC } \\
\text { Minimum } \\
\text { Wage }\end{array}$ \\
\hline \multicolumn{5}{|l|}{ Murder } \\
\hline 3 lags & $\begin{array}{c}-0.575^{* *} \\
(0.180)\end{array}$ & $\begin{array}{c}0.405 \\
(0.400)\end{array}$ & $\begin{array}{c}0.469 \\
(0.352)\end{array}$ & $\begin{array}{c}0.805 \\
(0.812)\end{array}$ \\
\hline 6 lag & $\begin{array}{c}-0.812 * * \\
(0.328)\end{array}$ & $\begin{array}{c}-0.759 \\
(0.498)\end{array}$ & $\begin{array}{c}0.766 \\
(0.582)\end{array}$ & $\begin{array}{c}-0.217 \\
(1.030)\end{array}$ \\
\hline 9 lags & $\begin{array}{c}-1.250 * * \\
(0.630)\end{array}$ & $\begin{array}{c}-0.922 \\
(0.797)\end{array}$ & $\begin{array}{c}1.065 \\
(0.765)\end{array}$ & $\begin{array}{c}1.934 \\
(1.602)\end{array}$ \\
\hline 12 lags & $\begin{array}{l}-0.134 \\
(0.739)\end{array}$ & $\begin{array}{l}-2.015 * * \\
(1.009)\end{array}$ & $\begin{array}{c}0.370 \\
(0.711)\end{array}$ & $\begin{array}{c}1.712 \\
(1.863)\end{array}$ \\
\hline \multicolumn{5}{|l|}{ Burglary } \\
\hline 3 lags & $\begin{array}{c}-0.189 * * \\
(0.082)\end{array}$ & $\begin{array}{c}-0.070 \\
(0.074)\end{array}$ & $\begin{array}{c}0.037 \\
(0.098)\end{array}$ & $\begin{array}{c}0.419 \\
(0.332)\end{array}$ \\
\hline $6 \mathrm{lag}$ & $\begin{array}{l}-0.151 \\
(0.122)\end{array}$ & $\begin{array}{c}-0.286 * * \\
(0.137)\end{array}$ & $\begin{array}{c}0.093 \\
(0.150)\end{array}$ & $\begin{array}{c}0.575 \\
(0.384)\end{array}$ \\
\hline 9 lags & $\begin{array}{l}-0.448^{*} \\
(0.233)\end{array}$ & $\begin{array}{c}-0.457 * * * \\
(0.157)\end{array}$ & $\begin{array}{c}0.125 \\
(0.145)\end{array}$ & $\begin{array}{c}0.446 \\
(0.491)\end{array}$ \\
\hline 12 lags & $\begin{array}{l}-0.404 \\
(0.334)\end{array}$ & $\begin{array}{c}-0.742 * * * \\
(0.278)\end{array}$ & $\begin{array}{c}0.119 \\
(0.198)\end{array}$ & $\begin{array}{c}0.362 \\
(0.664)\end{array}$ \\
\hline Assault & & & & \\
\hline 3 lags & $\begin{array}{c}-0.342 * * \\
(0.145)\end{array}$ & $\begin{array}{c}0.227 * * \\
(0.107)\end{array}$ & $\begin{array}{c}0.035 \\
(0.149)\end{array}$ & $\begin{array}{c}0.269 \\
(0.330)\end{array}$ \\
\hline $6 \mathrm{lag}$ & $\begin{array}{c}-0.808 * * * \\
(0.265)\end{array}$ & $\begin{array}{l}0.456^{*} \\
(0.274)\end{array}$ & $\begin{array}{l}-0.053 \\
(0.209)\end{array}$ & $\begin{array}{c}0.511 \\
(0.580)\end{array}$ \\
\hline 9 lags & $\begin{array}{l}-0.854 \\
(0.629)\end{array}$ & $\begin{array}{l}0.726 * \\
(0.378)\end{array}$ & $\begin{array}{l}-0.205 \\
(0.263)\end{array}$ & $\begin{array}{c}1.002 \\
(0.856)\end{array}$ \\
\hline 12 lags & $\begin{array}{l}-1.317 \\
(0.865)\end{array}$ & $\begin{array}{c}0.614 \\
(0.631)\end{array}$ & $\begin{array}{c}-0.349 \\
(0.330)\end{array}$ & $\begin{array}{c}1.203 \\
(1.003)\end{array}$ \\
\hline
\end{tabular}


Appendix Table A-7

(concluded)

\begin{tabular}{|c|c|c|c|c|}
\hline $\begin{array}{l}\text { Number of } \\
\text { Lags }\end{array}$ & $\begin{array}{c}\text { Own } \\
\text { Arrests }\end{array}$ & $\begin{array}{l}\text { Total Misd. } \\
\text { Arrests }\end{array}$ & $\begin{array}{c}\text { Unemployment } \\
\text { Rate }\end{array}$ & $\begin{array}{c}\text { NYC } \\
\text { Minimum } \\
\text { Wage }\end{array}$ \\
\hline \multicolumn{5}{|l|}{ Robbery } \\
\hline 3 lags & $\begin{array}{c}-0.295 * * * \\
(0.121)\end{array}$ & $\begin{array}{c}-0.136 * * \\
(0.070)\end{array}$ & $\begin{array}{c}-0.188 \\
(0.122)\end{array}$ & $\begin{array}{c}-0.279 \\
(0.287)\end{array}$ \\
\hline 6 lag & $\begin{array}{c}-0.662 * * * \\
(0.186)\end{array}$ & $\begin{array}{c}-0.394 * * \\
(0.205)\end{array}$ & $\begin{array}{c}-0.028 \\
(0.151)\end{array}$ & $\begin{array}{c}-0.297 \\
(0.456)\end{array}$ \\
\hline 9 lags & $\begin{array}{l}-0.376 \\
(0.383)\end{array}$ & $\begin{array}{c}-0.677 * * * \\
(0.258)\end{array}$ & $\begin{array}{c}0.057 \\
(0.202)\end{array}$ & $\begin{array}{l}-0.071 \\
(0.597)\end{array}$ \\
\hline 12 lags & $\begin{array}{l}-1.059 * * \\
(0.498)\end{array}$ & $\begin{array}{c}-0.930 * * * \\
(0.320)\end{array}$ & $\begin{array}{c}0.119 \\
(0.244)\end{array}$ & $\begin{array}{c}0.562 \\
(0.805)\end{array}$ \\
\hline $\begin{array}{l}\text { Motor } \\
\text { Vehicle } \\
\text { Theft }\end{array}$ & & & & \\
\hline 3 lags & $\begin{array}{c}-0.382 * * * \\
(0.120)\end{array}$ & $\begin{array}{l}-0.005 \\
(0.010)\end{array}$ & $\begin{array}{c}0.061 \\
(0.118)\end{array}$ & $\begin{array}{c}0.161 \\
(0.357)\end{array}$ \\
\hline 6 lag & $\begin{array}{c}-0.680^{* * *} \\
(0.188)\end{array}$ & $\begin{array}{c}-0.146 \\
(0.181)\end{array}$ & $\begin{array}{c}0.118 \\
(0.200)\end{array}$ & $\begin{array}{c}-0.028 \\
(0.468)\end{array}$ \\
\hline 9 lags & $\begin{array}{c}-0.792 * * * \\
(0.293)\end{array}$ & $\begin{array}{c}-0.724 * * * \\
(0.186)\end{array}$ & $\begin{array}{c}0.048 \\
(0.175)\end{array}$ & $\begin{array}{c}0.700 \\
(0.497)\end{array}$ \\
\hline 12 lags & $\begin{array}{l}-0.650 \\
(0.465)\end{array}$ & $\begin{array}{c}-1.223 * * * \\
(0.287)\end{array}$ & $\begin{array}{c}0.206 \\
(0.206)\end{array}$ & $\begin{array}{c}1.177^{* *} \\
(0.587)\end{array}$ \\
\hline
\end{tabular}

Note: $*, * *$, or $* * *$ signify statistical significance at the $10 \%, 5 \%$, and $1 \%$ levels, respectively. 